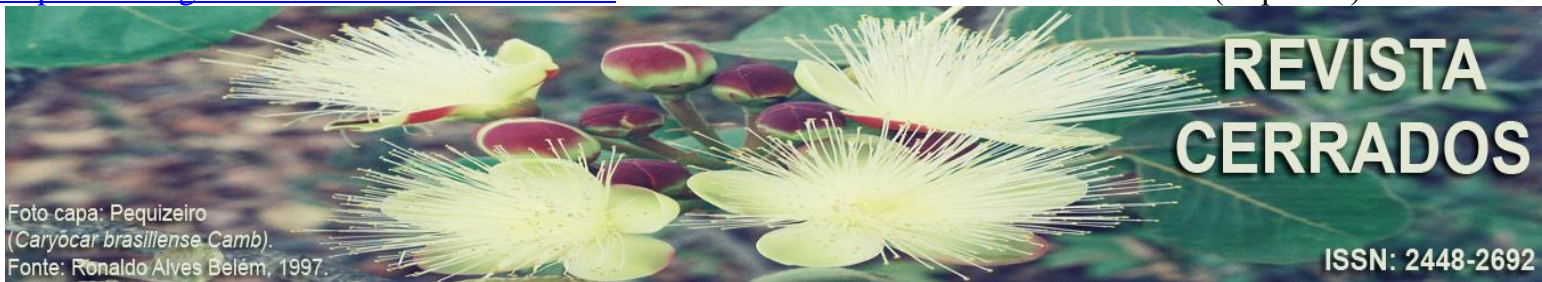

\title{
A DINÂMICA DO SETOR SUCROENERGÉTICO NO TRIÂNGULO MINEIRO/ALTO PARANAÍBA
}

\section{THE DYNAMICS OF THE SUCROENERGETIC SECTOR IN THE TRIÂNGULO MINEIRO/ALTO PARANAÍBA}

\author{
LA DINÁMICA DEL SECTOR SUCROENERGETICO EM \\ TRIÂNGULO MINEIRO/ALTO PARANAÍBA
}

\author{
Daniel Féo Castro de Araújo \\ Universidade de Brasília - UnB, Brasília, Distrito Federal, Brasil \\ E-mail: <Daniel.feo@gmail.com>. \\ Fernando Luiz Araújo Sobrinho \\ Universidade de Brasília - UnB, Brasília, Distrito Federal, Brasil \\ E-mail: < flasobrinho@gmail.com>.
}

\begin{abstract}
RESUMO
No início do século XXI, o agronegócio sucroenergético teve forte expansão no território brasileiro, especialmente nas regiões que estão no domínio morfoclimático do Cerrado, em função da construção de novas Unidades Agroindustriais Sucroenergéticas (UAS) e dos processos de financeirização e centralização do capital. O objetivo deste artigo é analisar o processo de modernização da cultura canavieira na produção agrícola na mesorregião Triângulo Mineiro/Alto Paranaíba. Para a realização da pesquisa, fizeram-se imprescindíveis os seguintes passos metodológicos: a) levantamento bibliográfico, leituras de material acadêmico já publicado sobre o tema (teses e dissertações, livros, periódicos, dentre outros) através de levantamento bibliográfico temático (específico sobre o setor sucroenergético e a cultura canavieira); b) pesquisa em campo que consistiu em levantamento, exame e organização de dados secundários da produção e da situação econômico-financeira das empresas, assim como de bases de dados do Instituto Brasileiro de Geografia e Estatística (IBGE).O Brasil se consolidou nas últimas décadas como uma das modernas fronteiras de expansão agrícola e agroexportador de produtos ligados ao agronegócio, especialmente no período pós - anos 2000, sob o paradigma da agricultura científica globalizada. Um conjunto de circunstâncias favoráveis, tanto técnica e político-econômica provocaram uma nova organização do setor, pautada na internacionalização do mercado e na difusão de inovações científico-tecnológicas, confirmando o caráter mais corporativo do território e a procura de novas áreas estratégicas. Concluímos que, a partir da organização dos dados e informações coletadas, o Triângulo Mineiro/Alto Paranaíba se tornou nas últimas décadas uma importante
\end{abstract}


ARAÚJO, D. F. C.; ARAÚJO SOBRINHO, F. L.

A DINÂMICA DO SETOR SUCROENERGÉTICO NO TRIÂNGULO MINEIRO/ALTO PARANAÍBA

Região Produtiva do Agronegócio impactando as relações e o mercado de trabalho, os fluxos migratórios, os municípios aonde a atividade se implantou, a articulação da região as redes de produção global, bem como questões ambientais decorrentes da produção em larga escala.

Palavras-chave: Modernização da agricultura. Agronegócio. Commodities. Globalização. Triângulo Mineiro/Alto Paranaíba.

\begin{abstract}
At the beginning of the 21st century, sugar-energy agribusiness had a strong expansion in the Brazilian territory, especially in the regions that are in the Cerrado's morphoclimatic domain, due to the construction of new Agroindustrial Sucroenergetic Units (UAS) and the processes of financialization and centralization of capital. The objective of this article is to analyze the process of modernization of the sugarcane culture in agricultural production in the Triângulo Mineiro / Alto Paranaíba mesoregion. To carry out the research, the following methodological steps were essential: a) bibliographic survey, readings of academic material already published on the topic (theses and dissertations, books, periodicals, among others) through a thematic bibliographic survey (specific about the sugar-energy sector and sugar cane culture); b) field research that consisted of surveying, examining and organizing secondary data on the production and economic and financial situation of companies, as well as databases from the Brazilian Institute of Geography and Statistics (IBGE). decades as one of the modern frontiers of agricultural expansion and agroexporter of products linked to agribusiness, especially in the post - 2000s period, under the paradigm of globalized scientific agriculture. A set of favorable circumstances, both technical and political-economic, provoked a new organization of the sector, based on the internationalization of the market and the diffusion of scientific and technological innovations, confirming the more corporate character of the territory and the search for new strategic areas. We conclude that, based on the organization of the data and information collected, the Triângulo Mineiro / Alto Paranaíba has become an important Agribusiness Productive Region in the last decades, impacting relations and the labor market, migratory flows, the municipalities where the activity was implemented, the articulation of the region with global production networks, as well as environmental issues arising from large-scale production.
\end{abstract}

Keywords: Modernization of agriculture. Agribusiness. Commodities. Globalization. Triângulo Mineiro/Alto Paranaíba.

\title{
RESUMEN
}

A principios del siglo XXI, los agronegocios de energía azucarera tuvieron una fuerte expansión en el territorio brasileño, especialmente en las regiones que se encuentran en el dominio morfoclimático del Cerrado, debido a la construcción de nuevas Unidades Agroindustriales de Energía de Azúcar (UAS) y los procesos de financiarización y centralización del capital. El objetivo de este artículo es analizar el proceso de modernización del cultivo de la caña de azúcar en la producción agrícola en la mesorregión Triângulo Mineiro / Alto Paranaíba. Para llevar a cabo la investigación, los siguientes pasos metodológicos fueron esenciales: a) encuesta bibliográfica, lecturas de material académico ya publicado sobre el tema (tesis y disertaciones, libros, publicaciones periódicas, entre otros) a través de una encuesta bibliográfica temática (específica sobre el sector de energía azucarera y Revista Cerrados, Montes Claros/MG, v. 18, n. 1, p. 248-277, jan./jun.-2020. 
ARAÚJO, D. F. C.; ARAÚJO SOBRINHO, F. L.

A DINÂMICA DO SETOR SUCROENERGÉTICO NO TRIÂNGULO MINEIRO/ALTO PARANAÍBA

cultivo de caña de azúcar); b) investigación de campo que consistió en encuestar, examinar y organizar datos secundarios sobre la producción y la situación económica y financiera de las empresas, así como bases de datos del Instituto Brasileño de Geografía y Estadística (IBGE). décadas como una de las fronteras modernas de la expansión agrícola y la agroexportadora de productos vinculados a la agroindustria, especialmente en el período posterior a la década de 2000, bajo el paradigma de la agricultura científica globalizada. Un conjunto de circunstancias favorables, tanto técnicas como político-económicas, provocaron una nueva organización del sector, basada en la internacionalización del mercado y la difusión de innovaciones científicas y tecnológicas, confirmando el carácter más corporativo del territorio y la búsqueda de nuevas áreas estratégicas. Concluimos que, en base a la organización de los datos y la información recopilada, el Triângulo Mineiro / Alto Paranaíba se ha convertido en una importante región productiva de agronegocios en las últimas décadas, impactando las relaciones y el mercado laboral, los flujos migratorios, los municipios donde se implementó la actividad. , la articulación de la región con las redes mundiales de producción, así como los problemas ambientales derivados de la producción a gran escala.

Palabras-clave: Modernização da agricultura. Agronegócio. Commodities. Globalização. Triângulo Mineiro/Alto Paranaíba.

\section{INTRODUÇÃO}

Desde o final do século XX e início do XXI, o setor do agronegócio canavieiro vem passando por transformações significativas pela expansão do meio técnico-científicoinformacional no território (SANTOS, 1994, 1996), e a composição de uma agricultura capitalista cada vez mais científica e globalizada (SANTOS, 2017) que traz em seu bojo diversas atividades direta e indiretamente articuladas ao agronegócio canavieiro, tendo como características a intensa modernização das atividades agrícolas, o uso intensivo de máquinas, insumos e defensivos agrícolas, bem como o controle do setor por grupos nacionais e internacionais altamente capitalizados e constituindo oligopólios (CAMELINI, 2011).

A política econômica brasileira se encaminhou gradualmente para o neoliberalismo a partir da década de 1990 (CASTILLO, 2007; FREDERICO, 2013). Deste modo, o neoliberalismo assume que a regulação pelo mercado é o modo mais hábil de controlar as atividades econômicas; em seguida, várias atividades como, por exemplo, o controle de preços, foram transferidas para o mercado durante este período (HARVEY, 2011). Este processo, por sua vez, acabou levando o país à privatização de seus ativos, a uma desregulação econômica extensiva e à liberalização do câmbio, do comércio exterior e da conta da balança comercial. O Estado brasileiro cumpriu importante papel político normativo, em consequência do contexto de alinhamento das políticas neoliberais e, sobretudo, da 
ARAÚJO, D. F. C.; ARAÚJO SOBRINHO, F. L.

A DINÂMICA DO SETOR SUCROENERGÉTICO NO TRIÂNGULO MINEIRO/ALTO PARANAÍBA

inserção da economia brasileira na globalização. Desde então, distintas políticas governamentais foram criadas para estimular o desenvolvimento setor sucroalcooleiro e tornálo um dos ramos mais expressivos da economia agrícola do país, como o Programa Nacional de Melhoramento da Cana-de-Açúcar (Planalsucar) e o Programa de Racionalização da Agroindústria Canavieira, em 1971, e o Programa de Apoio à Indústria Açucareira, em 1973 (SZMRECSÁNYI, 1979).

No entanto, a política mais importante para o setor foi o Programa Nacional do Álcool (Proálcool), criado em 1975 com o desígnio de fomentar a produção e o consumo do álcool combustível (anidro e hidratado) em meio à crise de desabastecimento da gasolina e do diesel provocado pelo choque do petróleo. De acordo com Moraes (2000) entre 1985 e 1989, quase $90 \%$ dos veículos vendidos no Brasil eram movidos à álcool. A queda nos preços do petróleo e a crise financeira do Estado, que comprometeu o destino de recursos para a manutenção do Proálcool, acarretaram no desestímulo à produção do etanol e no abandono do programa em 1989, bem como a extinção do IAA em 1990. Assim, após um longo período de intervenção direta nas atividades sucroenergéticas (1930-1990) e um curto período de ausência (anos 1990), o Estado retorna após os anos 2000 como um mediador entre as atividades sucroenergéticas e os usos do território, e fornece as condições técnicas e normativas necessárias à fluidez da produção (CAMELINI, 2013; SANTOS, 2017).

Deste modo, após os anos 2000, o fundamental instrumento empregado pelo Estado para o acolhimento das atividades sucroenergéticas no território são os investimentos por meio de Crédito Rural e empréstimos via Banco Nacional do Desenvolvimento (BNDES). A partir desse momento e em acordo com os ideais neoliberais que se consolidaram no país, o BNDES se tornou meio de financiamento das privatizações implantadas pelo Plano Nacional de Desestatização, de maneira que consagrou a condição das empresas estrangeiras, instituídas ou que almejavam se estabelecer no Brasil, receberem financiamento em igualdade de condições com empresas nacionais, o que estimulou a entrada de capitais estrangeiros nesse período (ARAÚJO, 2018). Nessa conjuntura, o Estado brasileiro mostrar-se como o mais expressivo da doutrina neoliberal, a privatização, que foi ainda uma estratégia central de desempenho dos Estados na promoção dos mercados financeiros (CHESNAIS 2005).

Mediante a este contexto, acontece os processos de fusões e aquisições de empresas que constituem uma forma rápida de uma empresa crescer, entrar em mercados, 
ARAÚJO, D. F. C.; ARAÚJO SOBRINHO, F. L.

A DINÂMICA DO SETOR SUCROENERGÉTICO NO TRIÂNGULO MINEIRO/ALTO PARANAÍBA

defender-se de aquisições indesejadas e aproveitar oportunidades de investimento (OLIVEIRA, 2016; MACÊDO, 2011; FAÇANHA, 2012; PITTA, 2016; SANTOS, 2017).

Com a territorialização do capital internacional destinado à Pesquisa, Desenvolvimento e Inovação PD\&I, resultando na difusão de inovações científicotecnológicas nas diferentes fases de produtividade e logísticas do setor sucroenergético que passa a constituir um complexo produtivo altamente competitivo e globalizado (CGEE, 2009; PESSÔA, 2007; SANTOS, 2017). Dito isto, afirma-se que a cultura agrícola da cana-de-açúcar é cada vez mais tecnificada e cientificizada, marcada pela utilização acentuada de maquinários e agroquímicos, assim como da biotecnologia, que permitiu a exploração de novas áreas do território nacional para o cultivo através da obtenção de novas variedades de cana-de-açúcar adaptadas às condições edafoclimáticas específicas (MESQUITA, 2015; SANTOS, 2017). Os investimentos resultaram também na implantação de modernas Unidades Agroindustriais Sucroenergéticas (UAS).

O estado de Minas Gerais e, mais especificamente, a mesorregião do Triângulo Mineiro e Alto Paranaíba, tem atraído novos investimentos do setor agroindustrial canavieiro, tanto no que diz respeito a grupos de outros estados da Federação como de investidores estrangeiros Cleps Jr. (2009), Thomaz Jr. (2010), Camelini (2011) Santos, (2017). No início da década de 1970, são criados planos de desenvolvimento visando a ocupação efetiva dos cerrados e o Programa de Desenvolvimento dos Cerrados (Polocentro), prevendo investimentos no desenvolvimento das agroindústrias e aumento da produtividade (PESSÔA, 2007; CLEPS JUNIOR, 2009; ARACRI 2012; PEREIRA, 2013). Medidas como mecanização da produção, criação de um sistema de armazenamento e transporte, uso de corretivos para o solo acido dos cerrados, capazes de modificar as características naturais de um solo arenoso e pobre em nutrientes, mas com uma topografia adequada ao uso de tratores, colhedeiras e introdução de sistemas de irrigação dos cultivos, foram adotadas para garantirem a implementação do programa (CASTILLO, 2015; SANTOS, 2017).

O Triângulo Mineiro e Alto Paranaíba é uma das mesorregiões brasileiras que incorporou de forma mais intensa as orientações do novo padrão agrícola brasileiro e modernizou-se ao longo dos anos 1970 e 1980, apesar da crise econômica se estabelecer na economia nacional. Além disso, a mesorregião torna-se grande produtora de cana de açúcar no final dos anos 1980. O desenvolvimento do setor agroindustrial no Triângulo Mineiro e Alto Paranaíba provocou grandes fluxos de investimentos de capital e de migrantes. De acordo com Bessa (2007), o Triângulo Mineiro possui localização geográfica privilegiada, devido à proximidade com o centro econômico do país e importantes cidades que configuram a rede urbana brasileira, como São Paulo, Brasília, Belo 
ARAÚJO, D. F. C.; ARAÚJO SOBRINHO, F. L.

A DINÂMICA DO SETOR SUCROENERGÉTICO NO TRIÂNGULO MINEIRO/ALTO PARANAÍBA

Horizonte, Goiânia, além da proximidade com os estados de São Paulo, Goiás e Mato Grosso do Sul, que possuem destaque no setor agropecuário, facilitando o desenvolvimento da economia regional. Segundo Castillo (2015), a Região Competitiva Agroindustrial do Setor Sucroenergético (RCASS) no Triângulo Mineiro/Alto Paranaíba, caracterizada por uma elevada especialização regional produtiva voltada para o setor, seguramente uma das áreas mais dinâmicas e estratégicas na macrorregião canavieira do Centro-Sul (SANTOS, 2017; SAMPAIO, 2015).

Objetiva-se neste artigo, portanto, analisar o processo de modernização da cultura canavieira na produção agrícola na mesorregião Triângulo Mineiro e Alto Paranaíba, Minas Gerais, Brasil. Para a realização da pesquisa, fizeram-se imprescindíveis os seguintes passos metodológicos: a) levantamento bibliográfico, leituras de material acadêmico já publicado sobre o tema (teses e dissertações, livros, periódicos, dentre outros) através de levantamento bibliográfico temático (específico sobre o setor sucroenergético e a cultura canavieira); b) pesquisa em campo que consistiu em levantamento, exame e organização de dados secundários da produção e da situação econômicofinanceira das empresas, assim como de bases de dados do Instituto Brasileiro de Geografia e Estatística (IBGE), Ministério da Agricultura, Pecuária e Abastecimento - MAPA, da Associação das Indústrias Sucroenergéticas de Minas Gerais SIAMIG, dos Portais Nova Cana e INFOCANA, sites das empresas, (tanto quantitativos, como qualitativos), que possibilitaram o mapeamento de informações, bem como observações e avaliações das transformações socioespaciais ocorridas, tanto no espaço urbano, quanto no rural, dos principais municípios no setor sucroenergético na região. Dentre as bases teóricas e argumentos acionadas, destacamos os trabalhos de Cleps Jr. (2009, 2016), Thomaz Jr. (2010), Camelini (2011), Elias (2013, 2017), Araújo Sobrinho; Ferreira (2019); Castillo (2015), Pitta et al. (2014), Silva (2012), Bernardes; Aruzzo (2016), Pêssoa (2007), Santos, (2017), Araújo (2018) Moraes (2000), dentre outros, que possibilitam reflexões teóricas acerca das inúmeras contradições e particularidades desencadeadas mediante ao setor sucroenergético.

\section{Consolidação da monocultura canavieira no território brasileiro}

No período de colonização do Brasil no século XVI, a cana-de-açúcar foi implantada no litoral brasileiro, na Zona da Mata Nordestina, no qual se concretizou como uma das fundamentais atividades econômicas durante extenso período histórico, com a produção e comercialização do açúcar - o denominado pelos historiadores e economistas como o "Ciclo do Açúcar” (PRADO JÚNIOR, 1963, FURTADO, 2005). A região Nordeste do Brasil torna-se possuidora dos procedimentos de produção em larga escala que mais tarde 
ARAÚJO, D. F. C.; ARAÚJO SOBRINHO, F. L.

A DINÂMICA DO SETOR SUCROENERGÉTICO NO TRIÂNGULO MINEIRO/ALTO PARANAÍBA

se desenvolveria para outras regiões do território brasileiro, tomando novas configurações, implantando novos instrumentos e tecnologias (ARAÚJO; ARAÚJO SOBRINHO 2020).

A produção canavieira era inicialmente voltada para exportação do açúcar devido, sobretudo, ao seu alto preço no mercado europeu. Segundo Andrade (1994) o desenvolvimento da produção canavieira oferecia condições de pagamento do capital agregado e com isso, priorizavam aberturas de portos, estradas e sobretudo, o desenvolvimento da navegação transoceânica e de cabotagem. Essa ampliação aconteceu através da repartição de terras a quem pudesse financiar a produção, comercialização e transporte da cana-deaçúcar.

De acordo com Andrade (2001), em relação ao Brasil, a produção e expansão canavieira têm como financiadores o capital internacional da época, no qual os engenhos centrais e as terras de cultivo eram de propriedade de famílias luso brasileiras. O que marcava os engenhos de açúcar era a propriedade dos senhores de engenho e de seus herdeiros, a utilização em larga escala de mão de obra escrava africana e, por outro lado, os subsídios e garantia de juros do capital aplicado pela Coroa Portuguesa, mas tinham ressalvas quanto à posse de terras para o cultivo de cana-de-açúcar que era concedida aos senhores de engenho pela Coroa Portuguesa (ANDRADE, 2001, p. 272). A ampliação da produção canavieira teve um papel imprescindível na história econômica do Brasil. Após dois séculos do descobrimento do Brasil, a cana-de-açúcar era o principal produto na estrutura da economia colonial até o Século XVIII e o período da Mineração. Deste modo, o Brasil era o maior produtor e exportador de açúcar do mundo. Não obstante das várias crises ocorridas no setor, em decorrência da perda da posição hegemônica do Brasil no mercado canavieiro mundial, a cana-de-açúcar permaneceu como o principal produto comercial de sua agricultura, condição que só veio perder em fins do século XIX, quando definitivamente se firmou o período do café.

De acordo com Santos (2009) nos séculos XIX e XX, a produção canavieira da região Nordeste estava nas mãos de alguns poucos grupos tradicionais e de origem familiar, que posteriormente migraram seu capital para o Centro-Sul do Brasil. Para Oliveira, (2016), essa estrutura política e social que se constituiu no Nordeste foi pautada, no trabalho escravo e nos grandes proprietários de terra que vem ao encontro com a atual concentração de poder, terras agrícolas e de capital nas mãos de alguns grupos tradicionais, especialmente nos principais estados produtores, entre eles: Alagoas, Pernambuco e Paraíba. Segundo Andrade Revista Cerrados, Montes Claros/MG, v. 18, n. 1, p. 248-277, jan./jun.-2020. 
ARAÚJO, D. F. C.; ARAÚJO SOBRINHO, F. L.

A DINÂMICA DO SETOR SUCROENERGÉTICO NO TRIÂNGULO MINEIRO/ALTO PARANAÍBA

(2001) as oligarquias políticas criadas por meio da cultura do açúcar, os grupos predominantes, constituídos na colonização, tiveram a habilidade de amoldar-se a cada período histórico, permanecendo até a atualidade no domínio da produção açucareira regional, ampliando os seus domínios para outras regiões e estados da Federação, constituindo uma oligarquia política que conservou e conserva por muito tempo o controle e a influência sobre as políticas e as estruturas de poder do Estado brasileiro.

No Século XX a produção e o fornecimento de açúcar para o mercado interno no Brasil estava ligado à produção dos estados do Nordeste e seus centros consumidores eram localizados no Centro-Sul. Dito isso, com a falta de infraestrutura rodoviária, o abastecimento interno de açúcar foi prejudicado. Essa condição foi definitiva para modificação do eixo produtivo da cana-de-açúcar do Nordeste para o Centro-Sul. Deste modo, foi essa expansão dos anos da Segunda Guerra mundial que deu início a mudança do eixo da produção canavieira e açucareira para os estados do Sudeste do país, uma transição que só foi concluída na década de 1950 (SZMRECSÁNYI; MOREIRA, 1991).

A partir das crises do petróleo nos anos 70 e o aumento da demanda por combustíveis fósseis, o Estado brasileiro inicia políticas de utilização de biocombustíveis a partir do uso em larga escala do álcool de cana-de-açúcar, adicionado à gasolina, e ampliação da produção e consumo de álcool deu-se essencialmente as custas dos incentivos financeiros e administrativos do Instituto do Açúcar e do Álcool - IAA que adotou como estratégia de controlar a produção de cana-de-açúcar, especialmente nos estados do Rio de Janeiro e São Paulo.

De acordo com Moraes (2000), o PROÁLCOOL pode ser caracterizado em quatro fases. A primeira, de 1975 a 1978, aconteceu pelo incentivo à ampliação da produção de etanol para utilização como combustível misturado à gasolina, por meio da instalação de destilarias anexas às usinas de açúcar. A motivação fundamental foi o primeiro choque de preços do petróleo no mundo, em outubro de 1973, e a necessidade de aproveitar a ociosidade do parque industrial sucroalcooleiro, que vinha sendo renovado e cujo elemento dinâmico, o mercado externo de açúcar, passara a sofrer queda na rentabilidade em face da redução acentuada nos preços do produto (MORAES, 2000).

A segunda fase, também motivada por outro choque do petróleo, ocorreu através da implantação de destilarias autônomas, e iniciou-se em 1979, quando os preços do petróleo desfecharam no mercado internacional. Esse período finalizou no episódio da falta de álcool Revista Cerrados, Montes Claros/MG, v. 18, n. 1, p. 248-277, jan./jun.-2020. 
ARAÚJO, D. F. C.; ARAÚJO SOBRINHO, F. L.

A DINÂMICA DO SETOR SUCROENERGÉTICO NO TRIÂNGULO MINEIRO/ALTO PARANAÍBA

hidratado nas bombas dos postos de combustível, em 1989. Nesse período, o PROÁLCOOL atingiu o auge, com a estruturação de uma rede de incentivos públicos fiscais e financeiros, abarcando desde os produtores de etanol até os consumidores finais (MORAES, 2000).

A terceira fase, iniciada após essa ocorrência, estende-se até a crise de superprodução de etanol, na safra 1999/2000. Nela preponderou um padrão de preços baixos do petróleo no mercado internacional, desestruturação do sistema de apoio e continuidade parcial do processo intervencionista governamental na produção e nos mercados dos produtos setoriais, o que redundou no excesso de produção de etanol e em queda de preços. $\mathrm{O}$ programa se susteve pelo consumo do anidro, dada a demanda da gasolina, e pela manutenção da frota de veículos a álcool em uso, mas a produção superou o consumo e gerou um estoque excedente que pressionou seus preços para baixo (MORAES, 2000).

A quarta fase, após 2000, iniciou-se com a renovação do PROÁLCOOL, principalmente através de ações corporativas, articulando cada vez mais segmentos econômicos, sociais e políticos, marcada pela liberação de preços dos produtos setoriais, introdução dos veículos flex fuel, possibilidades de aumento nas exportações de etanol e patamares de preços elevados, nos curto e médio prazos, de petróleo no mercado mundial (CAMELINI, 2013).

Nesse período mais recente, caracterizado pelo aumento da participação do Brasil no mercado externo de açúcar, que atualmente situa-se na média de $30 \%$ do mercado livre mundial (MORAES, 2000), em que a desregulamentação econômica forçou um ajuste setorial de mudanças organizacionais e produtivas, a questão da relação unidade industrial e agrícola aparentemente não mudou, fazendo com que se tenha mantida a integração vertical lavouraprocessamento de cana, reforçando o processo de concentração técnica/ produtiva, contraface da concentração fundiária do complexo, marcada pelo absoluto predomínio do esmagamento de cana própria (CAMELINI; CASTILLO, 2012). Na finalidade de complementar o cenário histórico, o item subsequente tem por objetivo analisar os fatores que acarretaram uma nova dinâmica para o setor sucroenergético brasileiro, despertando interesses futuros de empresas mundiais. 
ARAÚJO, D. F. C.; ARAÚJO SOBRINHO, F. L.

A DINÂMICA DO SETOR SUCROENERGÉTICO NO TRIÂNGULO MINEIRO/ALTO PARANAÍBA

Expansão recente e (Re) Organização Produtiva do Setor Sucroenergético em Minas Gerais e no Triângulo Mineiro/Alto Paranaíba

A cana-de-açúcar é cultivada em mais de 100 países em diferentes continentes. Em que pese à quantidade de países produtores, apenas 10 países concentram $80 \%$ da produção mundial, entre eles se destacam como os maiores players mundiais na produção dessa planta, são eles: Brasil, Índia, China, Tailândia, Paquistão, México, Colômbia, Austrália Guatemala e Estados Unidos. O Brasil tem se destacado na produção de cana-de- açúcar no espaço mundial, é possível perceber que o Brasil ocupa o primeiro lugar do ranking dos países produtores de cana-de-açúcar no ano 2018 (FAO 2019). O desenvolvimento das atividades do setor sucroenergético constituem imprescindível significado na economia do país. De acordo com os dados do cadastro do Ministério da Agricultura Pecuária e Abastecimento (2019) indicava o funcionamento de 371 usinas sucroenergéticas no país, a maioria delas (255 usinas) de produção mista (açúcar e etanol).

Atualmente a produção da cana-de-açúcar e seus derivados colocam o Brasil em posição de destaque no mercado internacional. A entrada do capital externo está relacionada à consolidação do uso do etanol como fonte alternativa ao combustível fóssil no Brasil e apresenta forte tendência a sua aceitação no mercado internacional a partir da abertura de novos mercados, por exemplo, na União Europeia, Coréia do Sul, EUA, Japão e Caribe (UNICA, 2020). Além disso, o país tem os menores custos de produção entre os principais competidores do mercado internacional e lidera o conhecimento da biotecnologia da cana, juntamente com a Austrália e África do Sul.

Fruto do desenvolvimento tecnológico do setor a partir da produção do etanol de segunda e terceira geração ${ }^{1}$ e da produção de biopolímeros ${ }^{2}$ (MACEDO, 2011), a agroindústria canavieira passou a ser denominada "setor sucroenergético" com alto nível de investimento tecnológico e diversificação crescente nos últimos anos. A cana tradicional, matéria-prima usada na fabricação de açúcar, teve seu aproveitamento ampliado para a produção do etanol e da bioeletricidade. Segundo a União das Indústrias de Cana-de-Açúcar

\footnotetext{
${ }^{1}$ Os biocombustíveis para transportes podem ser categorizados como de primeira geração, composta de culturas alimentares (trigo, cana-de-açúcar, beterraba e sementes oleaginosas), de segunda geração, composta por materiais lignocelulósicos (palha de cereais, colmos de milho, etc.), e os de terceira geração, composta por algas (McCormick, 2010).

${ }^{2}$ São materiais biocompatíveis e biodegradáveis que têm por objetivo substituir parcial ou totalmente o uso de plásticos de origem petroquímica.
}

Revista Cerrados, Montes Claros/MG, v. 18, n. 1, p. 248-277, jan./jun.-2020. 
ARAÚJO, D. F. C.; ARAÚJO SOBRINHO, F. L.

A DINÂMICA DO SETOR SUCROENERGÉTICO NO TRIÂNGULO MINEIRO/ALTO PARANAÍBA

UNICA (2020), a bioeletricidade produzida pela queima de bagaço de cana (biomassa) nas usinas de açúcar e álcool representa hoje 4,3\% da matriz energética nacional, resultando no crescimento da oferta do excedente desta fonte de energia para o Sistema Interligado Nacional de Energia Elétrica (SIN) nos últimos anos (figura 1).

Figura 1: Produção de eletricidade a partir da biomassa da cana-de-açúcar e possibilidade de comercialização com o Sistema Elétrico Brasileiro - Eletrobrás

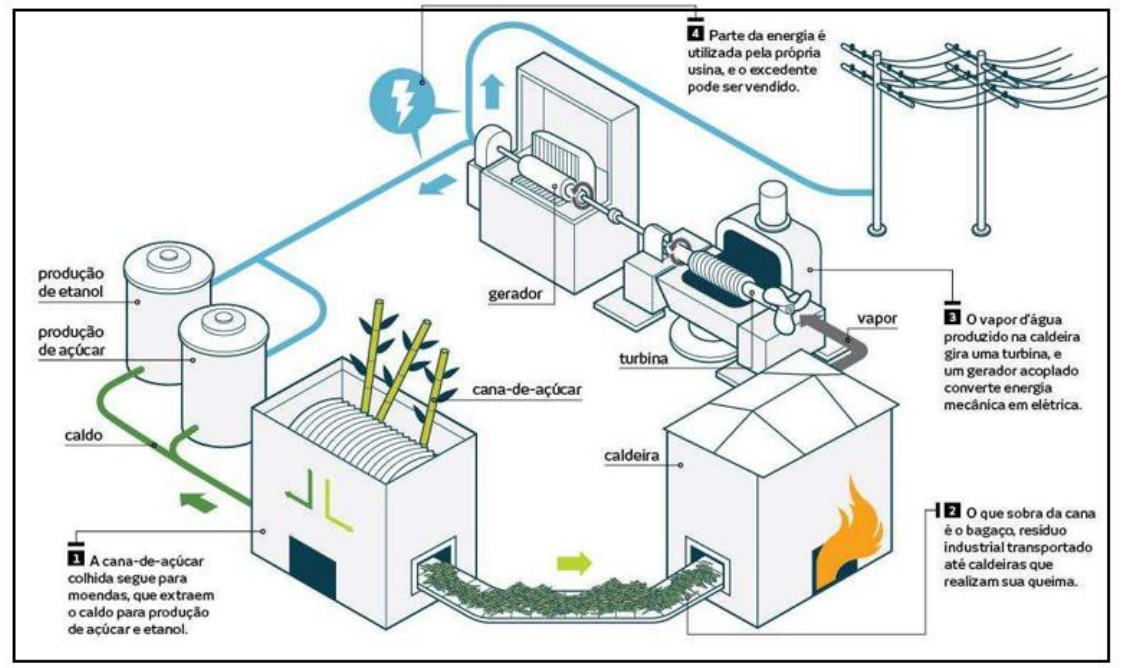

Fonte: RODRIGUES; OLIVEIRA (2012).

A privatização do setor elétrico, ocorrido no ano de 1999, abriu o mercado para novas possibilidades de produção independente de energia, permitindo que as usinas transformassem o seu sistema de queima do bagaço, antes aproveitado exclusivamente para aquecimento das caldeiras, fosse também proposto à geração e venda de energia termoelétrica. De acordo com os dados providos pela UNICA, presentemente o setor sucroenergético, por meio da bioeletricidade da cana, têm $7 \%$ da energia outorgada pela Agência Nacional de Energia Elétrica ANEEL, assim no Brasil, a energia produzida pelas usinas de açúcar e álcool ocupa a quarta colocação entre as fontes de geração da matriz energética em termos de capacidade instalada - atrás apenas das fontes hídrica, termelétricas (com gás natural) e eólicas (UNICA, 2020).

Assim, entre 2005 e 2015, a eletricidade ofertada na rede pelo setor sucroenergético aumentou de 0,8 Terrawat hora TWh para 20,4 TWh (gráfico 1), sendo que o total de energia disponibilizada no último ano equivaleu ao consumo anual de 10,4 milhões de residências (SANTOS, 2017). Desde 2014, em média 60\% de toda a eletricidade gerada pelas Revista Cerrados, Montes Claros/MG, v. 18, n. 1, p. 248-277, jan./jun.-2020. 
ARAÚJO, D. F. C.; ARAÚJO SOBRINHO, F. L.

A DINÂMICA DO SETOR SUCROENERGÉTICO NO TRIÂNGULO MINEIRO/ALTO PARANAÍBA

unidades agroindustriais é comercializada ao Sistema Interligado Nacional SIN, e 177 das 355 unidades que estavam operando em 2015 optaram por comercializar o excedente gerado (UNICA, 2020).

Gráfico 1 - Brasil: bioeletricidade consumida nas UAS e ofertada no SIN e preço médio de comercialização da energia elétrica (PLD - Preço de Liquidação das Diferenças) na região

Sudeste/Centro-Oeste, 2005-2015

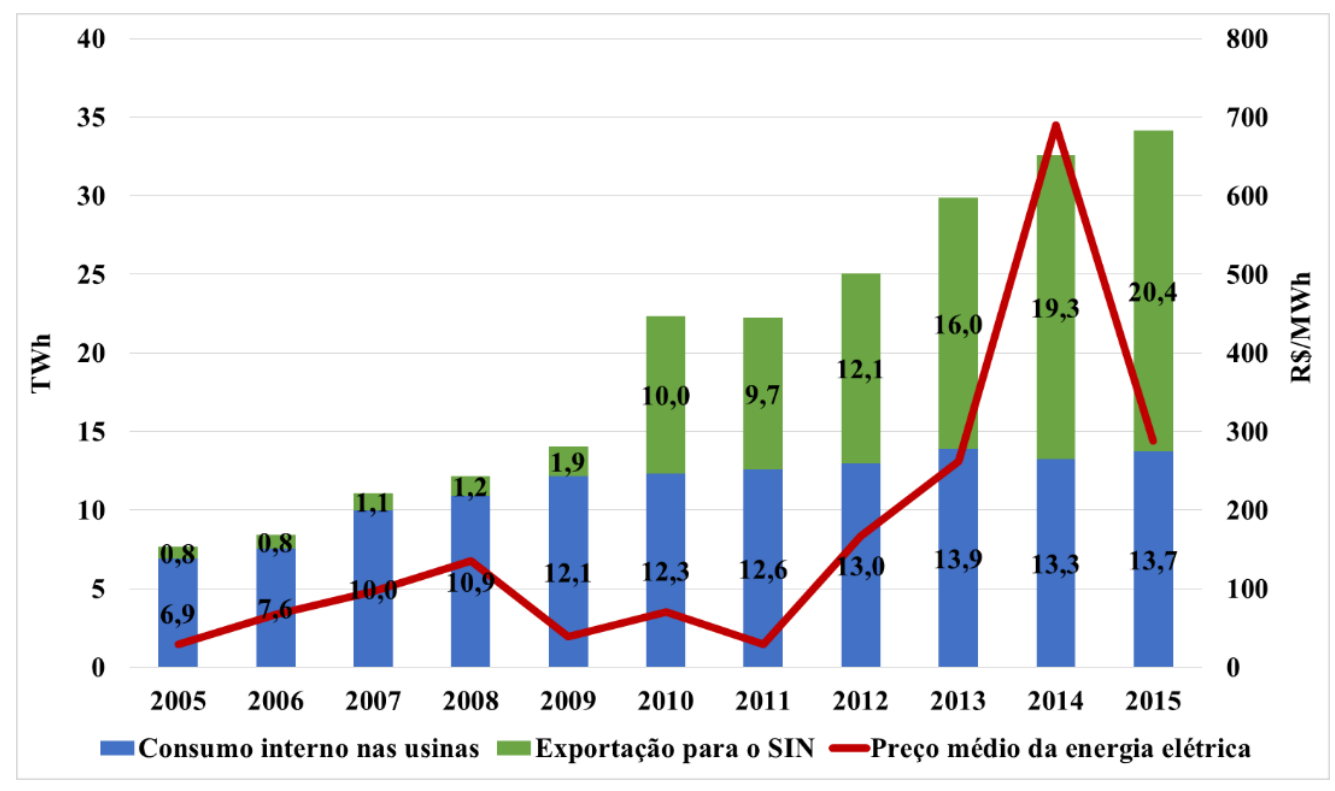

Fonte: EPE (2016); ÚNICA (2020); CCEE (2016). Organização: SANTOS, Henrique F. (2017)

Portanto, com a ascensão da bioenergia canavieira ocorreram importantes investimentos para a agroindústria sucroenergética no território brasileiro. Isto deriva de uma conjuntura internacional que converge para estimular o desenvolvimento de tecnologias renováveis e limpas no início do século XXI. Outro elemento do contexto internacional são as novas benfeitorias para aumentar à produção, com a justificativa das crises ambiental e energética, a reestruturação produtiva baseada em novidades tecnológicas e normativas, a nova espacialização da produção de açúcar, etanol, e energia, que impactam diretamente na expansão da cultura de cana-de-açúcar nas áreas do Cerrado, determinando a reorganização do setor no Brasil. Dito isso, a implicação deste processo é o desenvolvimento expressivo da produção nacional de cana-de-açúcar entre 2005 e 2010 que duplicou sua produção, (Gráfico 2), com o enriquecimento do setor sucroenergético e com aumento das exportações de derivados de cana. 
ARAÚJO, D. F. C.; ARAÚJO SOBRINHO, F. L.

A DINÂMICA DO SETOR SUCROENERGÉTICO NO TRIÂNGULO MINEIRO/ALTO PARANAÍBA

Atualmente, o mercado brasileiro de automóveis é, em sua maioria, composto por veículos flex fuel. Assim, o mercado cria estratégias de aumento do consumo de etanol, exigindo novo volume de produção do combustível. A macrorregião canavieira Centro-Sul (estados de São Paulo, Minas Gerais, Paraná, Goiás e Mato Grosso do Sul), foi responsável, no ano de 2014, pela produção de $21 \%$ da cana do mundo, muito mais do que a macrorregião Nordeste (3\%) e demais áreas produtoras isoladas no país (2\%) (SAMPAIO,2015).

Gráfico 2: Cultivo de cana-de-açúcar no Brasil (1990-2017)

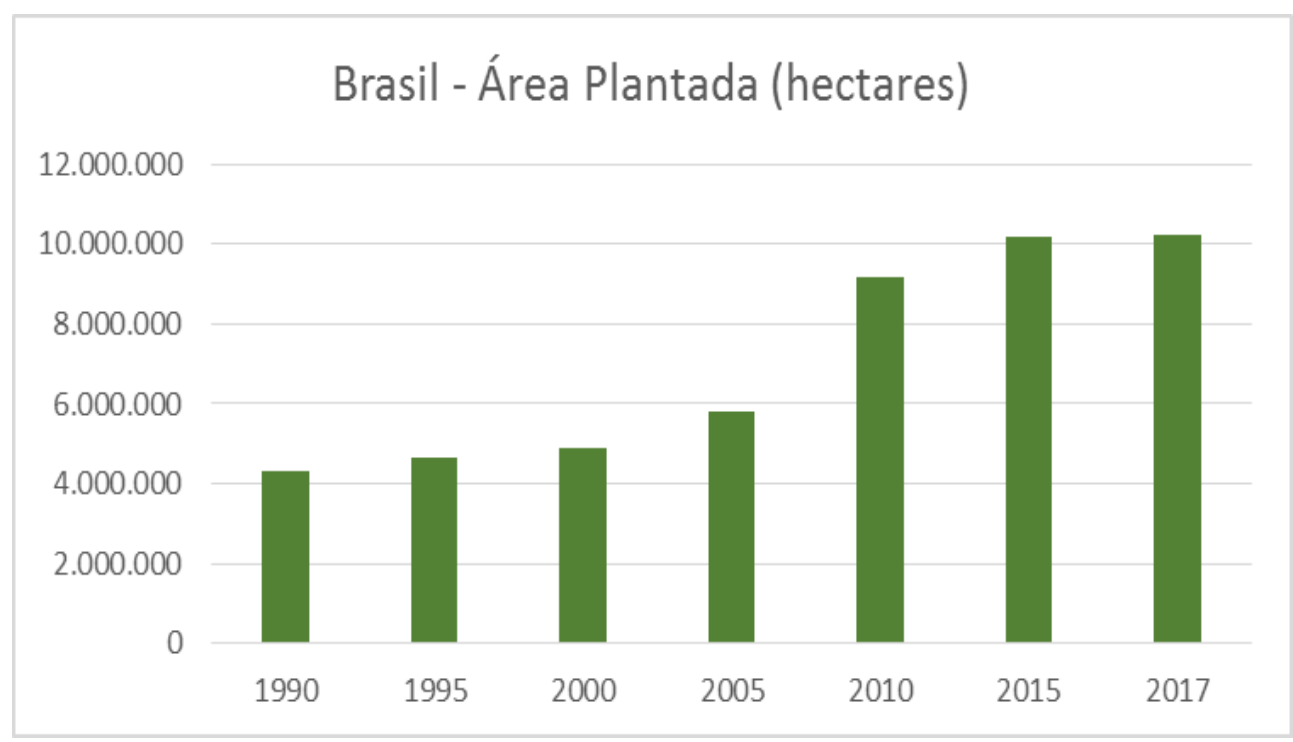

Fonte: IBGE (2017), Org. ARAÚJO, D. F. C., 2020.

De maneira especial, na última década, houve grande estímulo à produção de etanol, principalmente pelo surgimento dos veículos bicombustíveis (flex ${ }^{3}$ ) a partir dos anos de 2003 e 2004, capazes de utilizar qualquer combinação de gasolina e etanol, o que elevou significativamente a demanda interna por etanol hidratado ARAÚJO; SOBRINHO (2020). Com a elevação do preço do barril de petróleo, a intensificação das discussões sobre o aquecimento global e o papel dos combustíveis fósseis na problemática ambiental gerou-se uma alteração decisiva sobre as perspectivas do setor sucroenergético. De acordo com Associação Nacional dos Fabricantes de Veículos Automotores (ANFAVEA), constata-se que a produção de carros flexfuel no país, salta de aproximadamente 40 mil, em 2003, para atingir cerca de 1,8 milhões em 2015, como pode ser visto no gráfico 4 (ANFAVEA, 2020.)

\footnotetext{
${ }^{3}$ Carros com capacidade de funcionar movidos a álcool e a gasolina, ou com a mistura de ambos. Revista Cerrados, Montes Claros/MG, v. 18, n. 1, p. 248-277, jan./jun.-2020.
} 
ARAÚJO, D. F. C.; ARAÚJO SOBRINHO, F. L.

A DINÂMICA DO SETOR SUCROENERGÉTICO NO TRIÂNGULO MINEIRO/ALTO PARANAÍBA

Segundo o gráfico 4, que mostra a produção de veículos flex fuel no Brasil no período de 2003 a 2015 houve o crescimento da produção absoluta de carros bicombustível, pois no intervalo de trezes anos houve um aumento da produção na proporção de 45 vezes. Também tivemos um aumento gradativo da participação destes na produção dos veículos flex fuel na matriz produtiva anual com aumento de 2,6\% em 2003 para 89\% dos automóveis produzidos no território brasileiro no período de 2015 (ANFAVEA, 2020).

Gráfico 4: Aumento da produção de veículos e porcentagem dos veículos flexfuel no intervalo 2003-2015

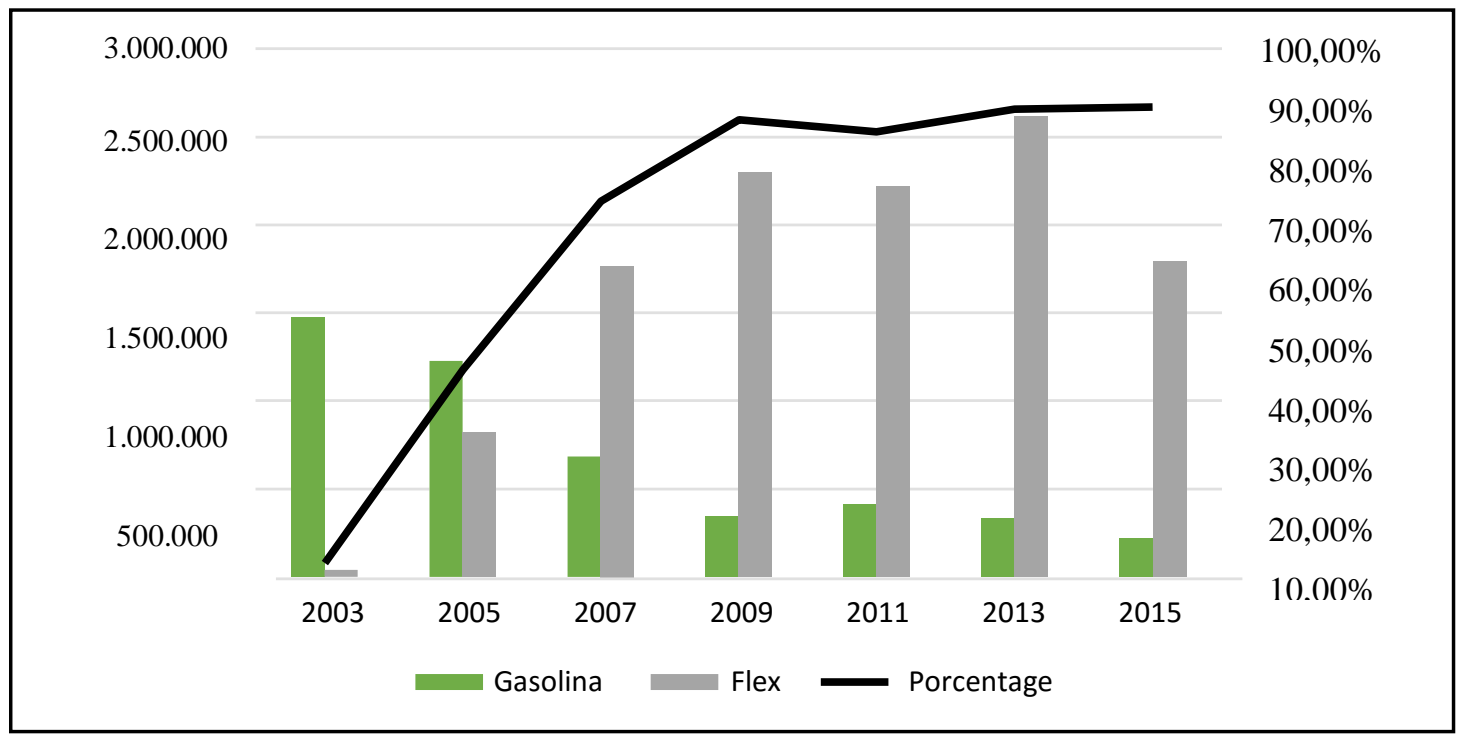

Fonte: ANFAVEA (2020). Org. ARAÚJO (2020).

Deste modo, configura-se o etanol como expressivo no abastecimento da frota nacional. De acordo com a Agência Nacional do Petróleo, Gás Natural e Biocombustíveis (ANP) destaca-se que no ano de 2017 foram consumidos 39,2 bilhões de litros de etanol no Brasil, dos quais 13,64 bilhões são representados pelo etanol hidratado ${ }^{4}$ e 25,56 bilhões de etanol anidro 5 . Em relação ao etanol anidro é importante ressaltar que, atualmente, normas federais impõem que toda gasolina do tipo comum comercializada no Brasil tenha em sua composição, uma porcentagem de $27 \%$ de etanol, enquanto que na gasolina aditivada este percentual seja de no máximo 25\% (ANP, 2020).

\footnotetext{
4 Anidro - o álcool anidro é bastante caracterizado pelo teor alcoólico mínimo de 99,3 (INPM), sendo composto apenas de etanol ou álcool etílico. É utilizado como combustível para veículos (Gasolina C) e matéria prima na indústria de tintas, solventes e vernizes.

${ }^{5}$ Etanol anidro é aquele misturado à gasolina.

Revista Cerrados, Montes Claros/MG, v. 18, n. 1, p. 248-277, jan./jun.-2020.
} 
ARAÚJO, D. F. C.; ARAÚJO SOBRINHO, F. L.

A DINÂMICA DO SETOR SUCROENERGÉTICO NO TRIÂNGULO MINEIRO/ALTO PARANAÍBA

Castillo (2015. p. 96) coloca que a dilatação do extrato populacional de renda média com promoção ao consumo de bens duráveis e principalmente a crise financeira de 2008, as políticas federais de incentivo à compra de veículos novos através da redução do Imposto sobre Produtos Industrializados IPI que, portanto, resultam num aumento das taxas de motorização que deram respaldo à reestruturação do setor sucroenergético no território brasileiro. Diante desta conjuntura favorece-se a produção total de etanol que desenvolve sua produção para o mercado interno e externo de modo considerado. Assim, podemos examinar o gráfico 5 que se segue e mostra as exportações brasileiras de etanol no período 2000-2017.

Gráfico 5: Exportações brasileiras de etanol no intervalo 2000 - 2017.

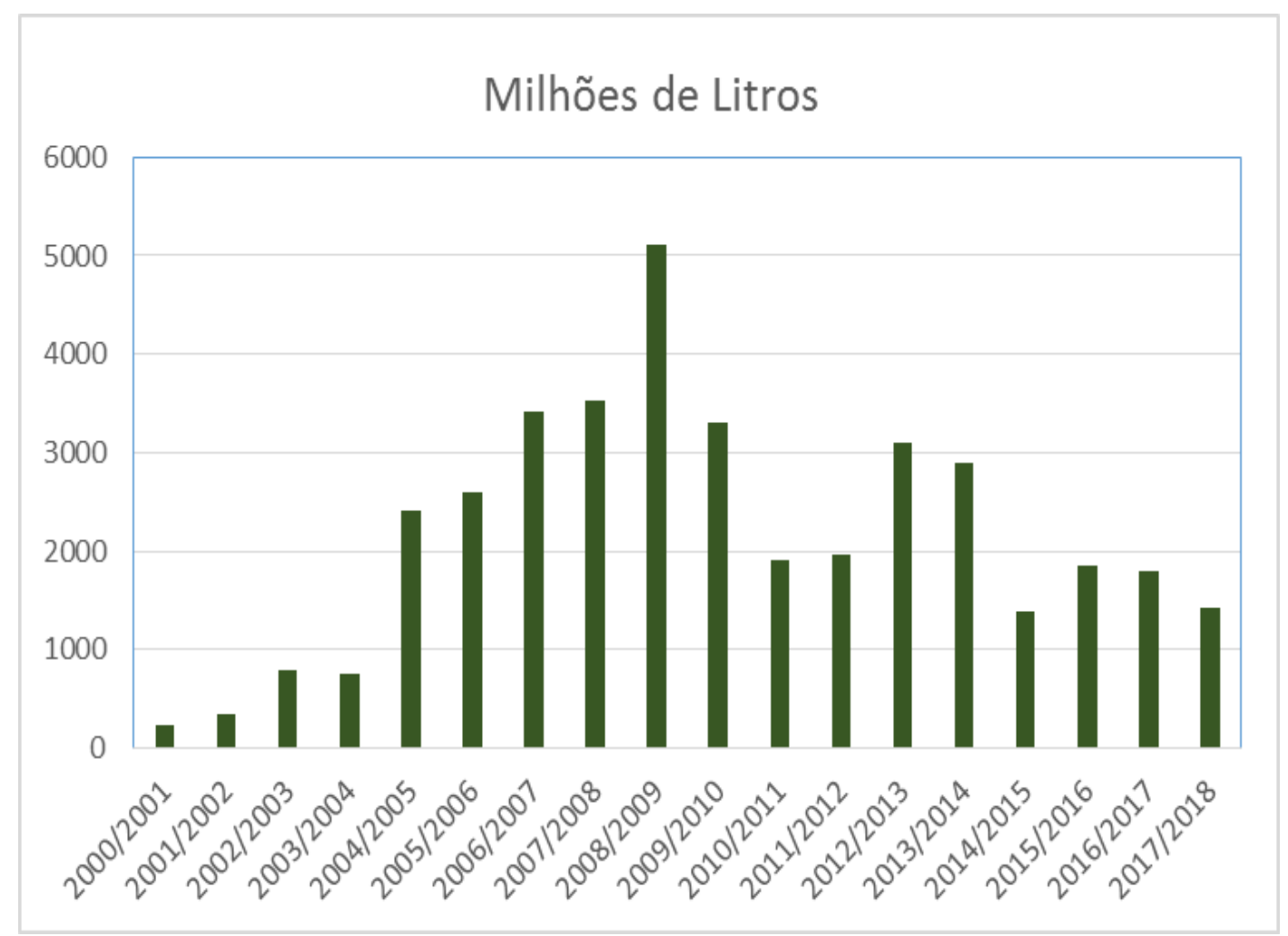

Fonte: UNICA (2018). Org. ARAÚJO (2020).

Ainda que a "crise internacional de 2008 " e a redução do preço do barril do petróleo em escala planetária tenham prejudicado a produção de álcool no período 2009 a 2011, esta tem um rebatimento e volta a ampliar o mercado, apesar das oscilações anuais. O modelo de desenvolvimento aceito no território brasileiro para se tornar soberano em bioenergia e, assim ter relevância nas exortações de etanol e de tecnologias empregadas na sua produção, se articula em um processo de desenvolvimento da monocultura de cana-de-açúcar. Ainda 
ARAÚJO, D. F. C.; ARAÚJO SOBRINHO, F. L.

A DINÂMICA DO SETOR SUCROENERGÉTICO NO TRIÂNGULO MINEIRO/ALTO PARANAÍBA

podemos ressaltar que a difusão deste cultivo constitui, especialmente, por meio da proliferação de grandes empresas agrícolas sobre o bioma Cerrado, a partir do estado de São Paulo em direção a Goiás - passando pelo Triângulo Mineiro e Alto Paranaíba - e em direção a Mato Grosso do Sul, passando também pelo norte do Paraná.

De acordo com Araújo (2018) no início da década de 1970, são criados planos de desenvolvimento visando a ocupação efetiva dos cerrados e o Programa de Desenvolvimento dos Cerrados (Polocentro), prevendo investimentos no desenvolvimento das agroindústrias e aumento da produtividade. Medidas como mecanização da produção, criação de um sistema de armazenamento e transporte, uso de corretivos para o solo, capazes de modificar as características naturais de um solo arenoso e pobre em nutrientes, mas com uma topografia adequada ao uso de tratores, colhedeiras e introdução de sistemas de irrigação dos cultivos, foram adotadas para garantirem a implementação do programa.

O Triângulo Mineiro é uma das regiões brasileiras que melhor incorporou as orientações do novo padrão agrícola brasileiro e modernizou-se ao longo dos anos 1970 e 1980, apesar da crise econômica se estabelecer na economia nacional. Ganham força culturas como o café e a soja. Além disso, a região torna-se grande produtora de cana de açúcar no final dos anos 1980 (CLEPS JR, 2009, 2016). O programa ainda privilegia os produtores provenientes de outras regiões, em detrimento dos proprietários tradicionais residentes na região, e levou muitos produtores a venderem suas terras e instalarem-se nas periferias das cidades. Esse processo configura uma lógica de exclusão de parte dos trabalhadores, não encontrando mais oportunidades de trabalho como arrendatários e parceiros, intensificou o contingente de mão de obra temporária, inclui precárias condições de vida e ocupação, salários baixos, extensas jornadas e condições inseguras de transporte. Sendo assim, observamos o espaço agrário no Triângulo Mineiro/Alto Paranaíba, caracterizado pela criação extensiva de gado de corte e pela agricultura de subsistência, modificar-se de forma dramática após a inauguração dos programas de ocupação dos cerrados, e fomentou de forma proeminente a mudança do perfil de produção regional com aumentos significativos em termos de produtividade, sem alterar, contudo, sua estrutura fundiária.

Durante as décadas de 1980 e 1990, é notório o destaque ao Cerrado nos programas direcionados ao desenvolvimento da agricultura, a região é tida como grande celeiro de alimentos como espaço de progresso e produção, de tecnologia avançada, uma vez incentivadora da exploração da agricultura de forma racional (CLEPS JR, 2009, 2016). 
ARAÚJO, D. F. C.; ARAÚJO SOBRINHO, F. L.

A DINÂMICA DO SETOR SUCROENERGÉTICO NO TRIÂNGULO MINEIRO/ALTO PARANAÍBA

Entretanto, não emergem, no discurso governamental, os indicadores do caráter excludente da modernização da agricultura, a concentração fundiária e a elevada sazonalidade do emprego agrícola no campo, grupos de trabalhadores encontram trabalho somente no pico da safra agrícola, úteis em culturas modernas como força de trabalho em tarefas ainda não mecanizadas.É neste contexto que a mesorregião Triângulo Mineiro/Alto Paranaíba, assim como outras regiões inseridas no domínio dos Cerrados, conhece significativa expansão dos cultivos na primeira década do século atual (Grafico 3, Figuras 2 e 3), afirmando-se como a principal região produtora de Minas Gerais (mais de 70\% da produção do estado).

Gráfico 3: Cultivo de cana-de-açúcar em Minas Gerais (1990-2017)

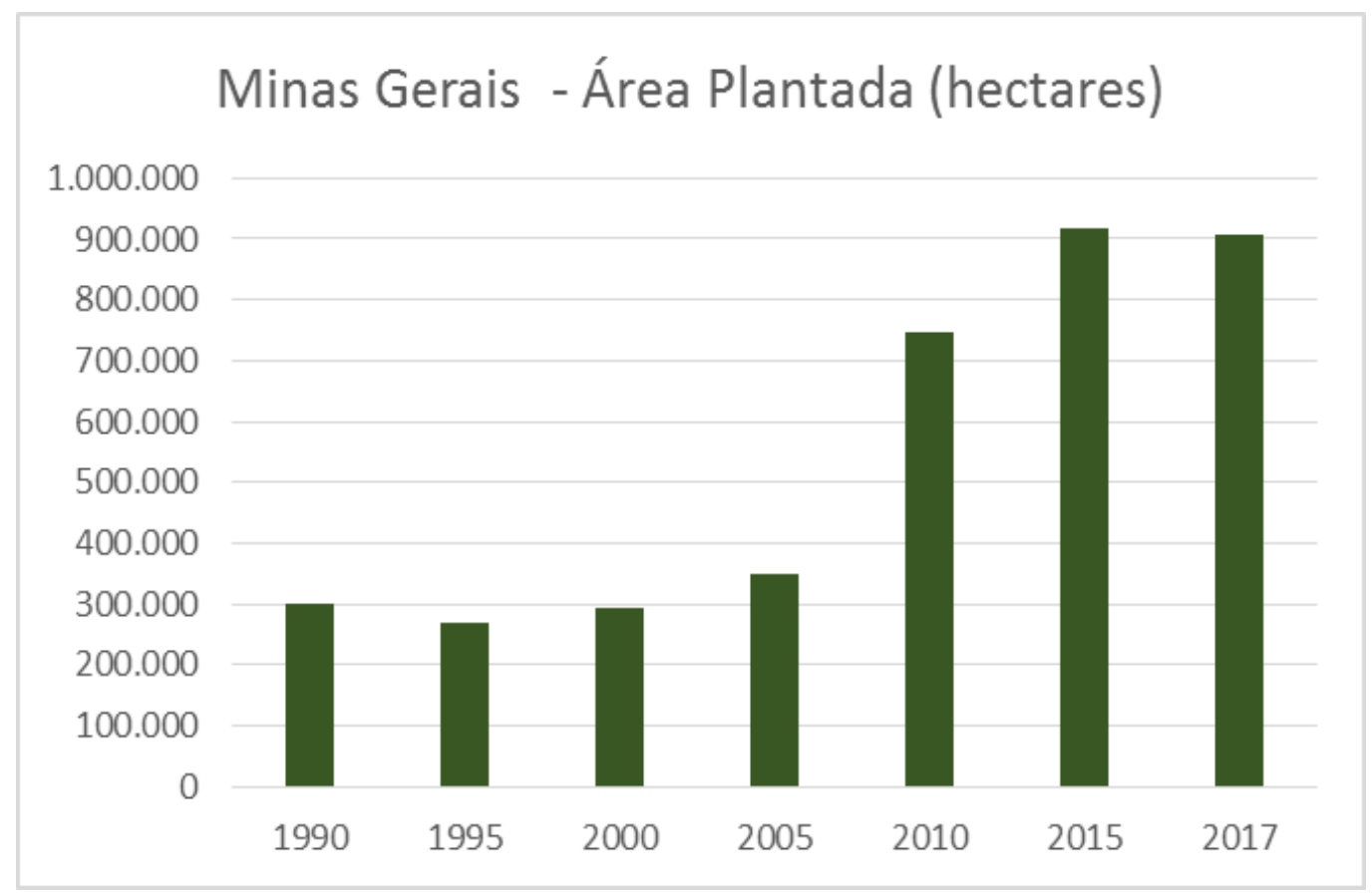

Fonte: IBGE (2017), Org. ARAÚJO, D. F. C., 2020.

Estudo publicado pelo IBGE (2017) apontou a presença, na mesorregião, de alguns dos municípios com maior produção de cana-de-açúcar no Brasil no ano de 2015, eram eles Uberaba (6,2 milhões de ton. $4^{\circ}$ maior produtor nacional) e Frutal ( 5 milhões de ton., $8^{\circ}$ maior município produtor do país no mesmo ano) A produção de cana-de-açúcar no Triângulo Mineiro e Alto Paranaíba é processada por 25 usinas sucroenergéticas, controladas por grupos nacionais e internacionais, detentores de unidades industriais em diversos municípios da mesorregião, como é o caso dos grupos Tércio Wanderley (Usinas Coruripe, quatro unidades na região), Delta Sucroenergia (três usinas), 
ARAÚJO, D. F. C.; ARAÚJO SOBRINHO, F. L.

A DINÂMICA DO SETOR SUCROENERGÉTICO NO TRIÂNGULO MINEIRO/ALTO PARANAÍBA

Companhia Mineira de Açúcar e Álcool (CMAA) (três usinas); e por grupos internacionais que ultimamente investem no setor (ADM, Bunge, Britsh Petroleum, Cargill e Dow Quimical).

A importância da produção canavieira regional frente ao contexto do Brasil, destaca que das 27 unidades federativas do país, somente São Paulo, Goiás e Mato Grosso do Sul produziram cana-de-açúcar em quantidades superiores à realizada no Triângulo Mineiro/Alto Paranaíba no ano de 2016 (50,3 milhões de toneladas). Podemos observar, em consonância com o gráfico 6, que distintos municípios da mesorregião em exame encontramse entre os maiores produtores de cana-de-açúcar do Brasil em quantidade absoluta. Portanto, entre os 21 primeiros listados no ranking, quatro localiza-se na mesorregião em questão, o que deixa o Triângulo Mineiro/ Alto Paranaíba atrás somente da mesorregião de Ribeirão Preto (SP), que conta com seis municípios na lista - sendo eles, Morro Agudo (SP), Barretos (SP), Guaíra (SP), Jaboticabal (SP), Ituverava (SP) e Batatais (SP).

Figura 2. Produção de cana-de-açúcar (em toneladas), Triângulo Mineiro/Alto Paranaíba -

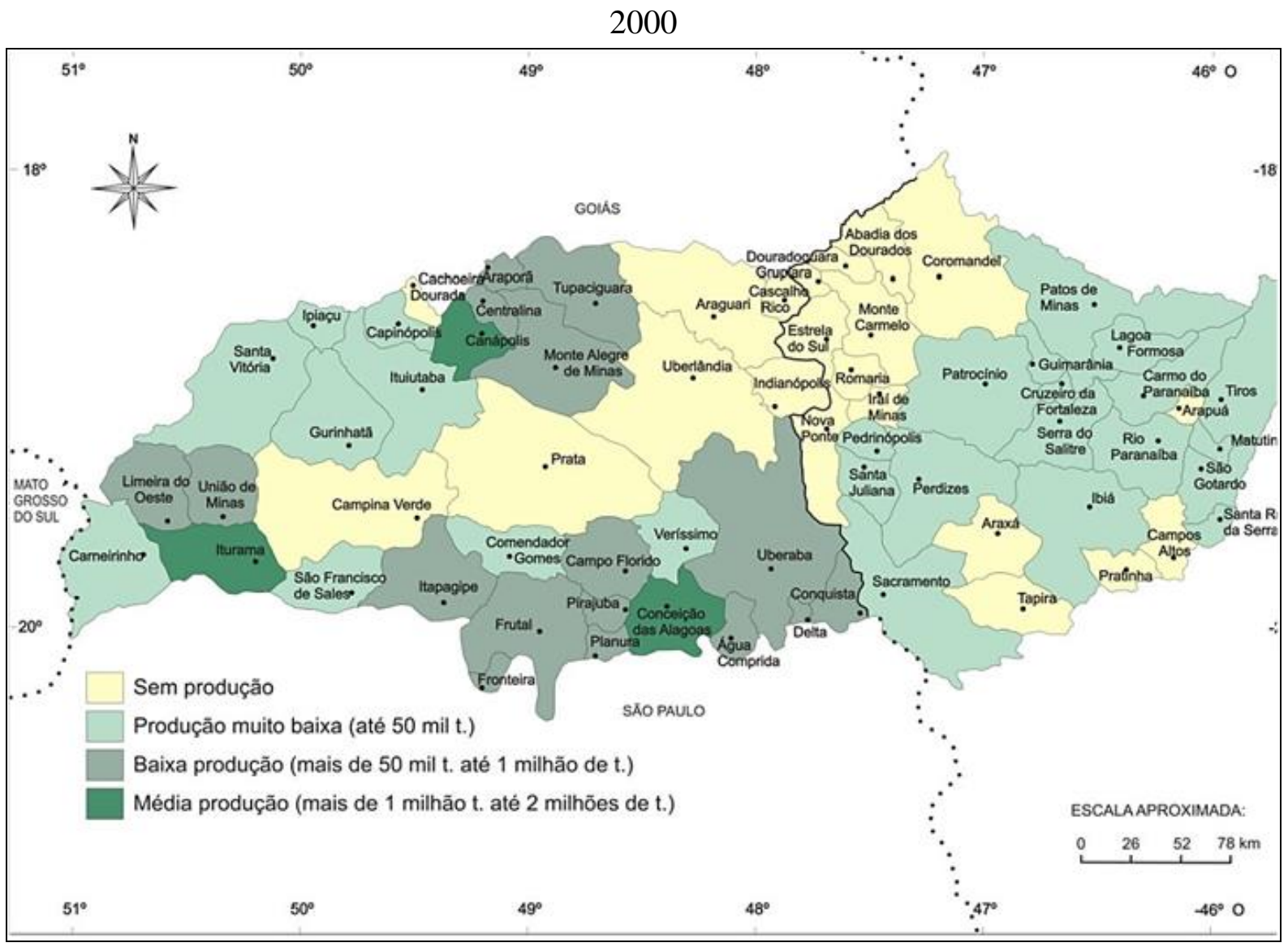

Fonte: PAM-IBGE. Org: PEREIRA, M. F. V. (2018). 
ARAÚJO, D. F. C.; ARAÚJO SOBRINHO, F. L.

A DINÂMICA DO SETOR SUCROENERGÉTICO NO TRIÂNGULO MINEIRO/ALTO PARANAÍBA

Figura 3. Produção de cana-de-açúcar (em toneladas), Triângulo Mineiro/Alto Paranaíba 2017

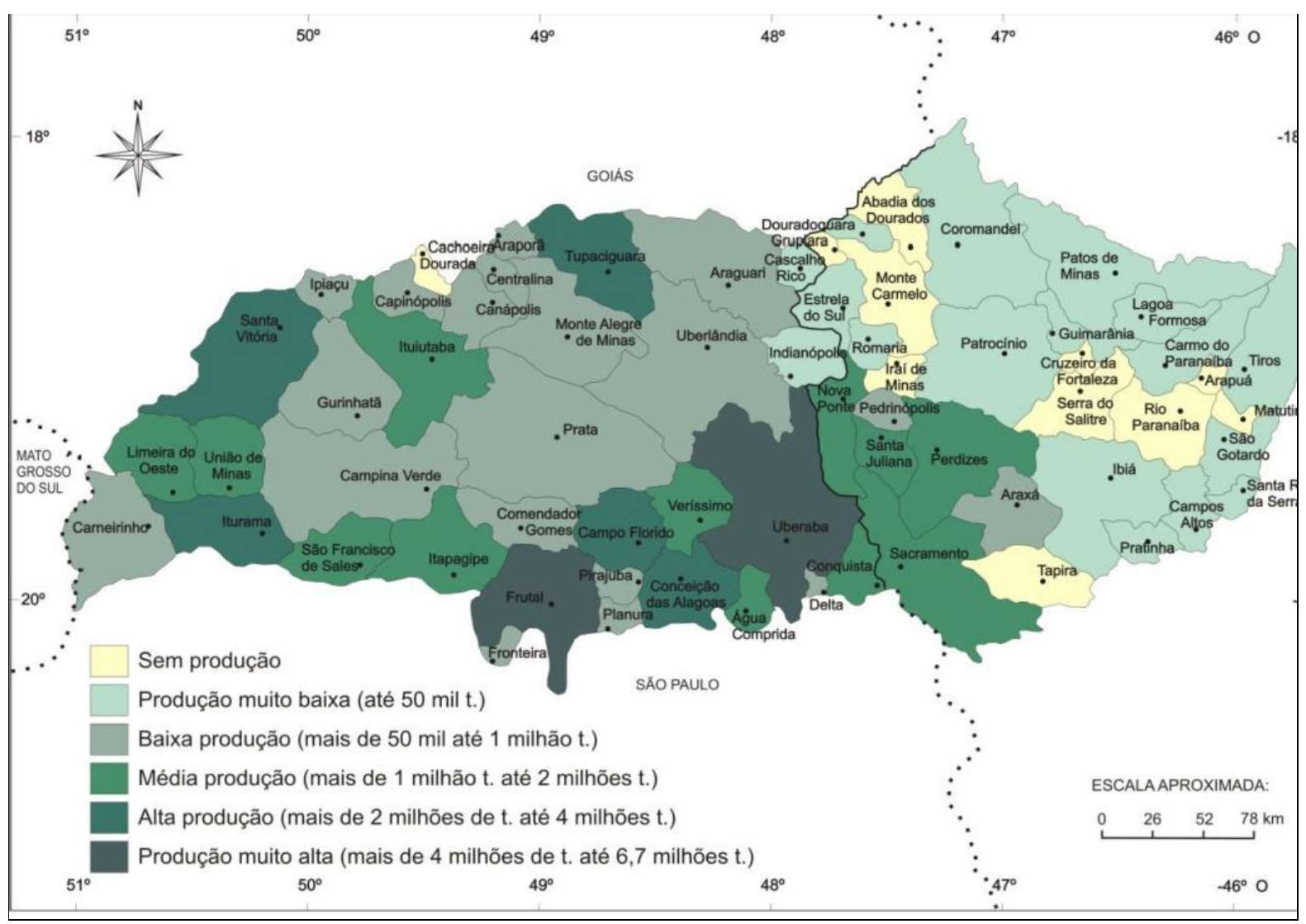

Fonte: PAM-IBGE. Org: PEREIRA, M. F. V. (2018).

Mediante os dados apontados pelo gráfico 6, que mostra que a mesorregião estudada tem dez municípios em que mais de $85 \%$ das áreas destinadas às lavouras temporárias estão ocupadas por canaviais, números que, igualmente, vão reforçar o processo de reorganização produtiva vinculada ao setor sucroenergético. Esta circulação se deve a um conjunto de características que envolvem a produção canavieira e de seus derivados. Examinando esta reorganização do território aponta-se para a condição de perpetuidade da cultura de cana-de-açúcar, a qual derivará em um maior rigor da utilização do território, atrapalhando a diversidade de outras culturas agrícolas nestas localidades (gráfico 7). Segundo Araújo e Araújo Sobrinho (2020. p. 161):

Um conflito estabelecido pelas usinas sucroalcooleiras é a perda de diversidade de produção agropecuária em detrimento da cana. Em paralelo há também problemas ambientais gerados tanto pela produção de rejeitos como o vinhoto utilizado como insumo agrícola, mas que acaba por infiltrar no solo e lençol freático escoando para 
ARAÚJO, D. F. C.; ARAÚJO SOBRINHO, F. L.

A DINÂMICA DO SETOR SUCROENERGÉTICO NO TRIÂNGULO MINEIRO/ALTO PARANAÍBA

os rios e tributários. Apesar de proibida a queima da cana antes da colheita, verificase inúmeros incêndios de grande porte nas lavouras desta cultura.

A isto, adiciona também as advertências ao armazenamento da cana-de-açúcar e a imprescindível proximidade com a unidade processadora que está ligada a rentabilidade via logística, pois isto é uma das características do setor que tornam a economia e mesmo o território dos municípios muito vulneráveis, já que passam a se tornar dependentes de um único setor econômico/produtivo.

Ainda em concordância com o que é apresentado no Gráfico 7, quando observamos em uma conjuntura nacional considerando-se a soma de culturas temporárias e permanentes, dos 3.625 municípios brasileiros que produziram cana-de-açúcar em 2010, em 682 desses municípios essa cultura respondeu por mais de $50 \%$ de toda a área ocupada pela agricultura, em 213 desses municípios esse índice oscilou entre 90 e 100\% (CASTILLO, 2015, p. 102).

Gráfico 6: Municípios da mesorregião Triangulo Mineiro/Alto Paranaíba dentre os maiores produtores de cana-de-açúcar no Brasil em 2016

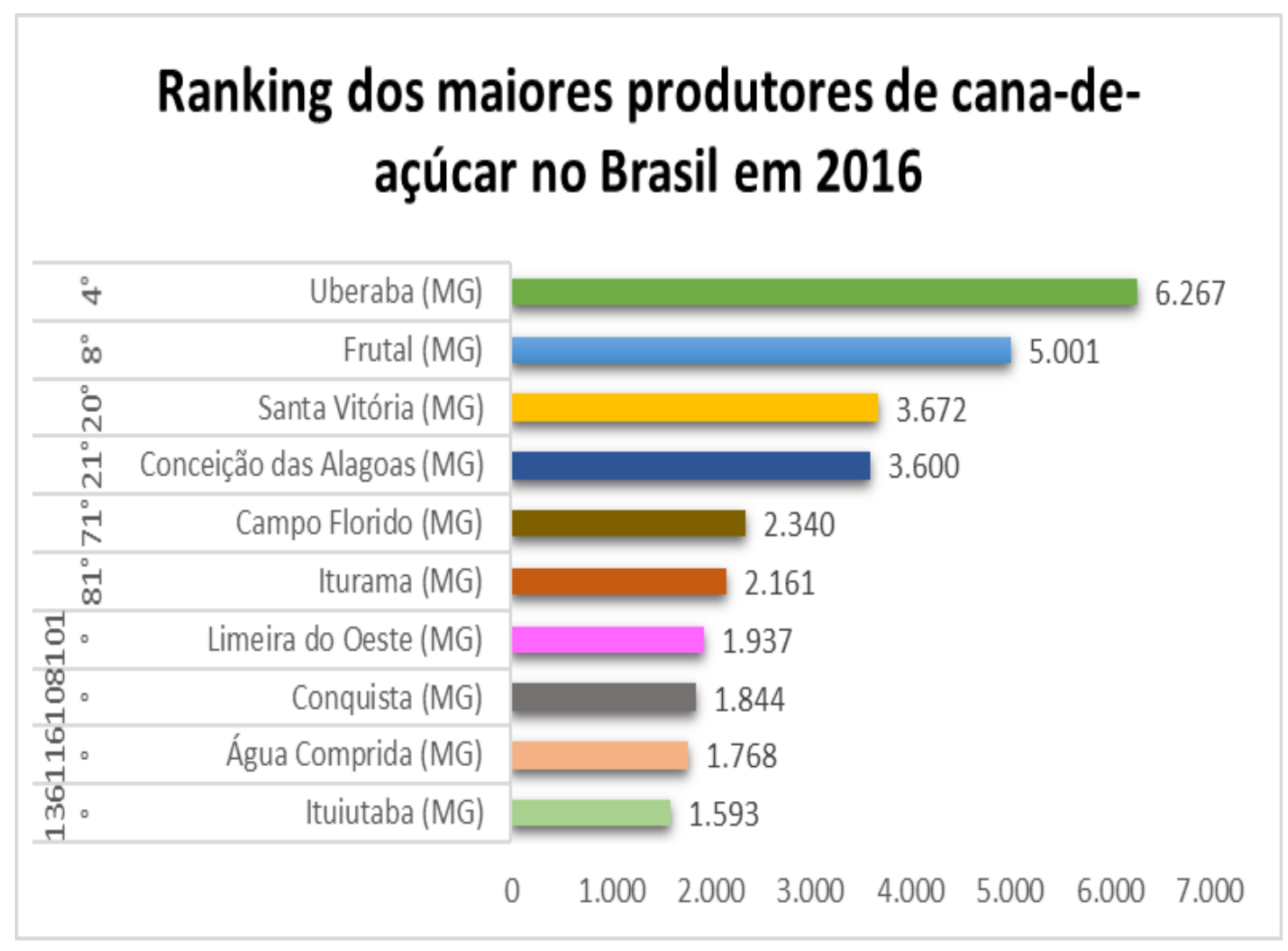

Fonte: IBGE/Cidades (2017); SIDRA (2020). Org. ARAÚJO (2020).

Revista Cerrados, Montes Claros/MG, v. 18, n. 1, p. 248-277, jan./jun.-2020. 
ARAÚJO, D. F. C.; ARAÚJO SOBRINHO, F. L.

A DINÂMICA DO SETOR SUCROENERGÉTICO NO TRIÂNGULO MINEIRO/ALTO PARANAÍBA

Gráfico 7: Municípios da mesorregião Triângulo Mineiro/ Alto Paranaíba que possuem mais de 85\% da área plantada ocupada por cana-de-açúcar em 2016.

\section{Razão Cana x Lavoura Temporária (\%)}

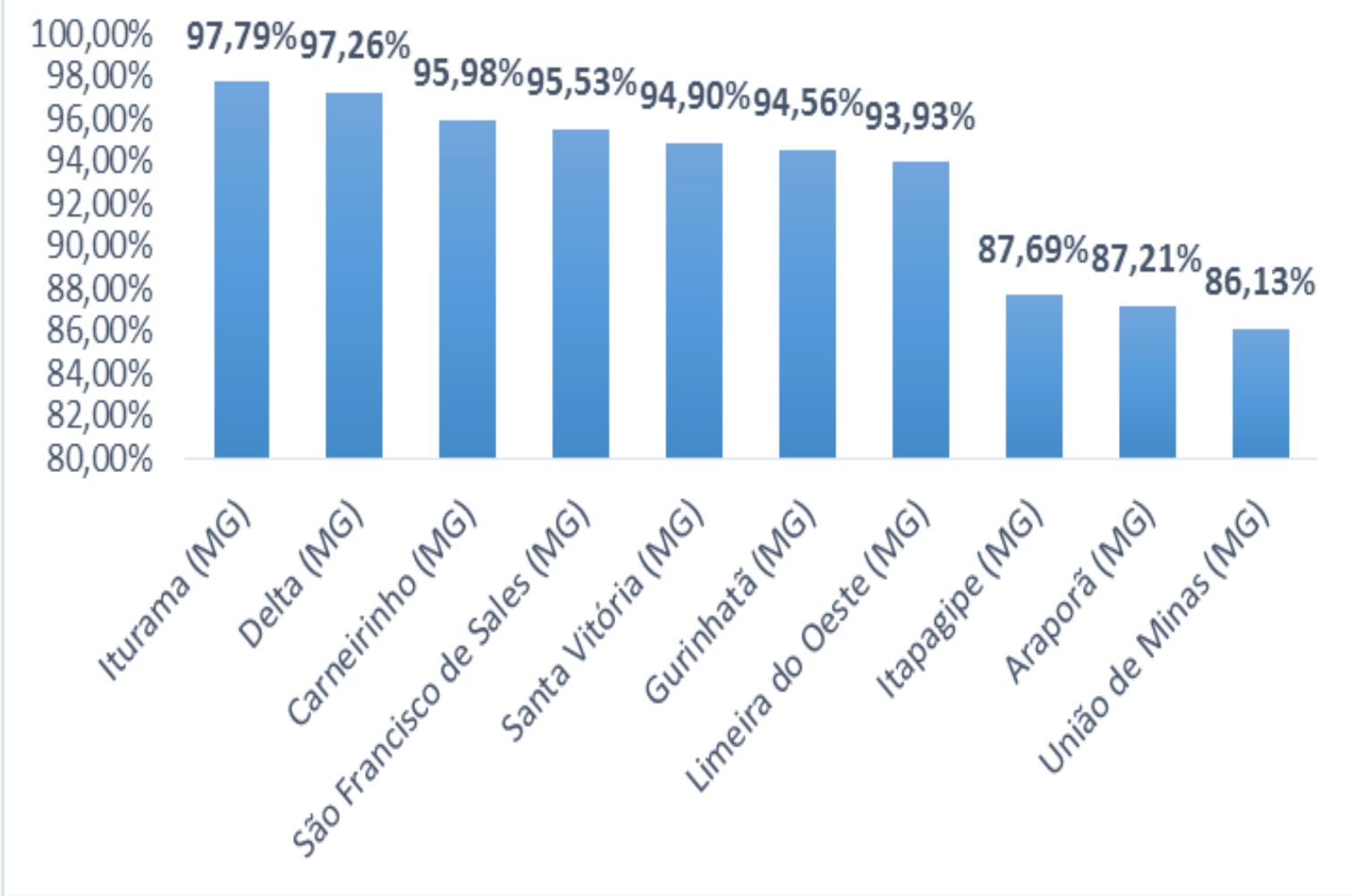

Fonte: IBGE/Cidades (2017); SIDRA (2020). Org. ARAÚJO (2020).

É indispensável perceber que todos estes indicadores são implicação e resultante do crescimento de número de usinas, portanto como do conjunto de reajustamentos proporcionados através destes processos. Diante deste panorama, dados atribuídos pelo Sindicato da Indústria de Fabricação do Álcool no Estado de Minas Gerais (SIAMIG) apontam que, após o ano de 2001 doze usinas foram instaladas na mesorregião Triângulo Mineiro/Alto Paranaíba, totalizando 25 unidades na safra de 2016 (SIAMIG, 2018). Assim sendo, das 38 usinas instaladas no estado de Minas Gerais, $65,8 \%$ (25 usinas) se localizam na mesorregião em destaque, como pode ser observado no gráfico 8 . 
ARAÚJO, D. F. C.; ARAÚJO SOBRINHO, F. L.

A DINÂMICA DO SETOR SUCROENERGÉTICO NO TRIÂNGULO MINEIRO/ALTO PARANAÍBA

Gráfico 8: Usinas em funcionamento na mesorregião Triângulo Mineiro/ Alto Paranaíba

$(2000-2016)$

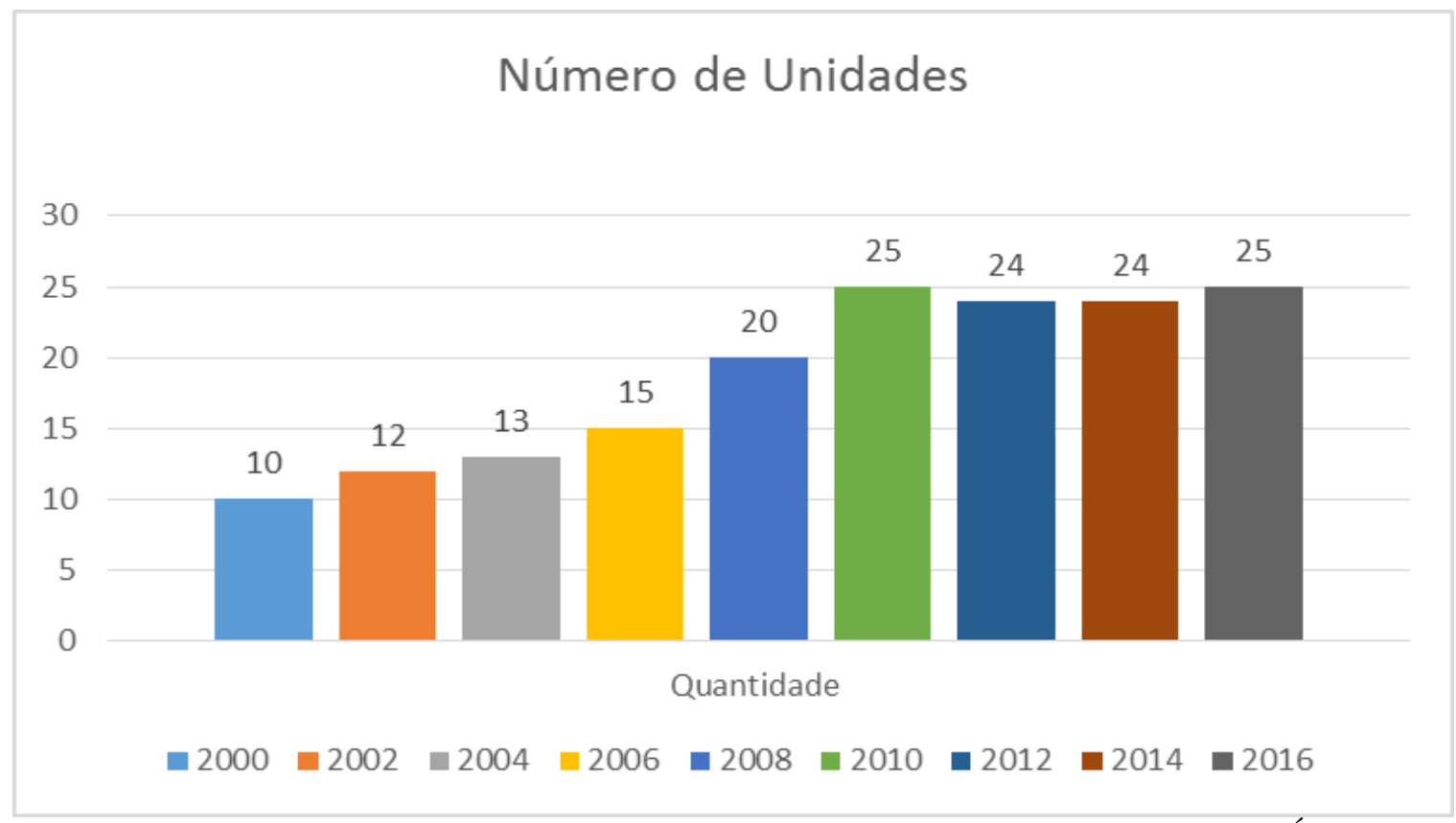

Fonte: SIAMIG (2020. n.p.); NOVACANA (2017. n.p.); UNICADATA (2020. n.p). Org. ARAÚJO (2020).

Concluímos que os elementos apresentados e analisados indicam que o agronegócio sucroenergético passou por transformações no transcorrer do tempo e reorganizou os territórios dos municípios onde se instala, sendo uma das principais atividades agrícolas das últimas décadas nos municípios da mesorregião Triângulo Mineiro/Alto Paranaíba. Contudo, vale observar que, apesar da extraordinária intensidade do processo em escala regional, alguns municípios, especialmente os que têm usinas instaladas em seus territórios, são os que reconhecem um processo mais intenso de crescimento canavieiro, oferecendo números produtivos proporcionalmente ainda mais consideráveis e tendo nesta cultura um papel proeminente no que se acena às modificações socioterritoriais em escala local.

\section{CONSIDERAÇÕES FINAIS}

Analisar como o setor sucroenergético se desenvolve diante do espaço agrícola regional e brasileiro, da mesma maneira como desenvolver uma investigação das dinâmicas envoltas nos processos de produção, processamento e comercialização de cana-de-açúcar e seus derivados, esforçando-se em prol de uma abordagem totalizante ligada aos seus mais distintos procedimentos, mostrou-se ainda mais complexo e desafiador que inicialmente 
ARAÚJO, D. F. C.; ARAÚJO SOBRINHO, F. L.

A DINÂMICA DO SETOR SUCROENERGÉTICO NO TRIÂNGULO MINEIRO/ALTO PARANAÍBA

pensado. Assim, a produção e processamento de cana-de-açúcar uma das demais commodities agrícolas produzidas no Brasil cumpre importante abrangência sobre a uso e enraizamento dos territórios em escala local. A entrada destas empresas origina um conjunto de alterações nos municípios analisados por esta pesquisa. Desta maneira, territorialidades pretéritas se romperam, dando lugar a novos arranjos produtivos e relações sociais, ambientais e econômicas.

Foi possível observar, a partir da sistematização de dados e informações, que houve significativa ampliação do setor sucroenergético no Triângulo Mineiro/Alto Paranaíba entre os anos 2000 e 2016, atrelado às condições geográficas favoráveis de cultivo e processamento de cana-de-açúcar existentes na região, e às aquisições realizadas por grandes grupos nacionais e internacionais altamente capitalizados e articulados ao mercado financeiro global, determinados na consolidação do setor na pauta de produção e consumo no Brasil e no mundo. Os novos investimentos de capital, a partir da entrada da complexa e altamente capitalizada rede técnica e logística ao longo das várias etapas de produção e processamento do setor sucroenergético, contribuem para a dinamização das atividades agrícolas e a ampliação da produção de riquezas. Assim, o Produto Interno Bruto (PIB) dos dez municípios conhece crescimento substancial.

Deste modo, as probabilidades de negociação do etanol combustível e da bioeletricidade no mercado interno e a elevação dos preços do açúcar no mercado internacional, esclarecem ainda os múltiplos investimentos na construção de unidades de produção no bioma Cerrado e na aquisição de unidades abandonadas na região, abrangendo assim a competência de acúmulo de capital dos agentes econômicos envolvidos no setor canavieiro.

Todavia, com os desdobramentos da crise econômica e financeira internacional de 2007-2008 no setor sucroenergético acabou se estabilizando na região, principalmente posteriormente ao ano de 2013. Anteriormente, existiam múltiplos projetos de implantação de novas usinas inclusive por empresas transnacionais. Apesar de algumas unidades permaneçam previstas para serem inseridas, muitas obras ainda não saíram do projeto, pois houve diminuição dos recursos ofertados pelo Banco Nacional de Desenvolvimento Econômico e Social (BNDES), principal canal de financiamento das instalações agroindustriais. 
ARAÚJO, D. F. C.; ARAÚJO SOBRINHO, F. L.

A DINÂMICA DO SETOR SUCROENERGÉTICO NO TRIÂNGULO MINEIRO/ALTO PARANAÍBA

Não obstante, é imprescindível denunciar como esse processo de modernização da agricultura e consolidação do agronegócio globalizado sucedido não se concretizou de maneira homogênea e pleno de contradições socioespaciais. Com o processo de desenvolvimento das monoculturas e atividades agroindustriais de grupos hegemônicos do capital, diferentes impactos de ordem socioambiental se colocaram na região acarretando conflitos com as comunidades locais que consomem e praticam uma agropecuária voltada para policultura, autonomia e diversidade alimentar das populações dos municípios e que são fundamentais a produção e acesso regular desses alimentos, atendendo aos critérios da Segurança Alimentar e Nutricional (SAN), como é o caso de camponeses e/ou agricultores familiares. As contradições deste processo com o desenvolvimento das forças produtivas no campo em especial ao agronegócio globalizado tiveram implicações, por exemplo, no forte êxodo rural, na expropriação socioeconômica de camponeses e algumas comunidades tradicionais, na degradação ambiental nas áreas do bioma cerrado.

\section{REFERÊNCIAS}

ANDRADE, M. C. de. Espaço e tempo na agroindústria canavieira de Pernambuco. Estudos Avançados, São Paulo, v. 15, nº 43, p. 267-280, 2001.

ANDRADE, M. C. de. A terra e o homem no Nordeste: contribuição ao estudo da questão agrária no Nordeste. 5. ed. São Paulo: Atlas, 1986.

ANDRADE, M. C. Modernização e pobreza: a expansão da agroindústria canavieira e seu impacto ecológico e social. São Paulo: Editora Unesp, 1994. 250 p.

ARACRI, L. A. Reestruturação produtiva, território e difusão de inovações no campo: a agricultura de precisão em Mato Grosso. Rio de Janeiro: Arquimedes, 2012.

ARACRI, L. A. dos S.; AMARAL, G. M. de O.; LOURENÇO, T. C. M. A expansão do cultivo da soja e as transformações do espaço agrário no Cerrado Mineiro. Revista de Geografia (PPGEO/UFJF), Juiz de Fora, v. 2, n. 1, p. 1-9, 2011.

ARAÚJO, D. F. C. de. O lado amargo da cana: estudos sobre trabalhadores migrantes no setor sucroenergético no pontal do triângulo mineiro. 2018. 176 f. Dissertação (Mestrado) - Curso de Programa de Pós-graduação em Ciências Sócias, Instituto de Ciências Sociais, Universidade Federal de Uberlândia, Uberlândia, 2018.

ARAÚJO, D. F. C. de; ARAÚJO SOBRINHO, Fernando Luiz. A cultura agrícola da cana-deaçúcar no Brasil: contribuição ao estudo dos territórios rurais e suas contradições e conflitos. Geopauta, [S.1.], v. 4, n. 1, p. 162-183, abr. 2020. ISSN 2594-5033. Disponível em: <http://periodicos2.uesb.br/index.php/geo/article/view/6303>. Acesso em: 12 maio 2020. 
ARAÚJO, D. F. C.; ARAÚJO SOBRINHO, F. L.

A DINÂMICA DO SETOR SUCROENERGÉTICO NO TRIÂNGULO MINEIRO/ALTO PARANAÍBA

ARAUJO S. F. L; FERREIRA, L. C. G. A produção canavieira e o mito do progresso: agronegócio e agricultura familiar na microrregião Ceres, Goiás. Revista Patry Ter, Brasília, vol. 2 |n. 1 | abril 2019.

ARAUJO S. F.L; PIZARRO, R. E. C. A construção do agronegócio na região de planejamento Sudoeste Goiano. Campos Neutrais - Revista Latino-Americana de Relações Internacionais, Porto Alegre, v. 1, n. 2, p. 91-106, 2019.

ARAUJO S. F. L; RUFO, T. F. Modernização agrícola nos Cerrados piauienses: novas dinâmicas socioespaciais e transformações urbanas em Bom Jesus e Uruçui, Piauí. Revista Equador (UFPI), v. 5, n. 4 (Edição Especial 03), p.164 - 186, 2018.

ASSOCIAÇÃO NACIONAL DOS FABRICANTES DE VEÍCULOS AUTOMOTORES ANFAVEA. Anuário da Indústria Automobilística Brasileira. 2020. Disponível em: http://anfavea.com.br/estatisticas. Acesso em: 13 de abril de 2020.

BERNARDES, J. A. Metamorfoses no Setor Sucroenergético: emergência de contradições. In: BERNARDES, J. A.; SILVA, C. A. da; ARRUZZO, R. C. (Org.). Espaço e energia: mudanças no setor sucroenergético. Rio de Janeiro: Lamparina, 2013.

BERNARDES, J. A; ARRUZZO, R. C. Expansão do setor sucroenergético e a História dos lugares: a questão territorial dos Guarani e Kaiowá em Mato Grosso do Sul. Revista da ANPEGE, [S.1.], v. 12, n. 17, p. 5-33, jun. 2017. Disponível em: <http://ojs.ufgd.edu.br/index.php/anpege/article/view/6411 >. Acesso em: 24 jun. 2020.

BESSA, K. A. Dinâmica da Rede Urbana no Triângulo Mineiro: convergências e divergências entre Uberaba e Uberlândia. Uberlândia: Composer, 2007.

BRAY, S. C. As Políticas do Instituto do Açúcar e do Álcool e do Programa Nacional Álcool e Suas Influências na Área Açucareira - Alcooleira de Catanduva. In:RUAS, D. G. G.; FERREIRA, E. R.; BRAY, S. C. (Orgs.). A agroindústria sucroalcooleira nas áreas canavieiras de São Paulo e Paraná. 1. ed. Rio Claro: IGCE/UNESP, 2014. v. 1. 213 p.

BRAY, S. C . O Proálcool e as transformações nas áreas canavieiras do estado de São Paulo. Boletim de Geografia Teorética, Rio Claro, v. 22, n. 43-44, p.21-26, 1992.

CAMELINI, J. H. Regiões competitivas do etanol e vulnerabilidade territorial no Brasil = o caso emblemático de Quirinópolis, GO. 2011. 137 f. Dissertação (mestrado) - Universidade Estadual de Campinas, Instituto de Geociências, Campinas, SP.

CAMELINI, J. H. Agricultura de precisão para cana-de-açúcar: expressão local de um processo global. In: ANAIS XIV ENCUENTRO DE GEÓGRAFOS DE AMÉRICA LATINA. Lima, Peru 2013.

CASTILLO, R. A. Dinâmicas recentes do setor sucroenergético no Brasil: competitividade regional e expansão para o bioma Cerrado. GEOgraphia, [S.1.] v. 17, p. 95-119, 2015. 
ARAÚJO, D. F. C.; ARAÚJO SOBRINHO, F. L.

A DINÂMICA DO SETOR SUCROENERGÉTICO NO TRIÂNGULO MINEIRO/ALTO PARANAÍBA

CASTILLO, R. Agronegócio e Logística em Áreas de Cerrado: expressão da agricultura científica globalizada. Revista da Anpege, [S.1.], v. 3, p. 33-43, 2007.

CHESNAIS, F. A finança mundializada. Tradução de Rosa Marques e Paulo Nakatani. São Paulo: Boitempo, 2005. $255 \mathrm{p}$

CGEE. Centro de Gestão e Estudos Estratégicos. Bioetanol de cana-de-açúcar: uma oportunidade para o Brasil. Brasília, DF: CGEE, 2009. Disponível em:

http://www.cgee.org.br/atividades/redirect.php?idProduto=5913. Acesso em: maio/2020.

CLEPS JUNIOR, J. Concentração de poder no agronegócio e (des)territorialização: os impactos da expansão recente do capital sucroalcooleiro no Triângulo Mineiro. Caminhos de Geografia, Uberlândia, v. 10, n. 31, p. 249-264, 2009.

CLEPS JUNIOR, J. Expansão e territorialização das agroindústrias do setor sucroenergético em Minas Gerais e o contexto das lutas sociais no campo. Revista Geonordeste, [S.1.], v. 27, p. 123-137, 2016.

DELGADO, G. C. Do Capital Financeiro na Agricultura à Economia do Agronegócio: Mudanças Cíclicas em Meio Século: (1965-2012). Porto Alegre- RS: Editora da UFRGS, 2012. v. 01.142 p.

DELGADO, G. C. Especialização primária como limite ao desenvolvimento.

Desenvolvimento em Debate, [S.1.], v.1, n.2, p.111-125, 2010.

ELIAS, D. Construindo a noção de Região Produtiva do Agronegócio. In: OLIVEIRA, H. C. M. de; CALIXTO, M. J. M. S.; SOARES, B. R. Cidades Médias e Região. São Paulo: Cultura Acadêmica, 2017.

ELIAS, D. Regiões produtivas do agronegócio: notas teóricas e metodológicas. In:

BERNARDES, J. A., SILVA, C. A., ARRUZZO, R. C. (Org.). Espaço e energia: mudanças no paradigma sucroenergético. Rio de Janeiro: Lamparina, 2013a, p. 201-220.

ELIAS, D. Globalização, Agricultura e Urbanização no Brasil. Revista ACTA Geográfica, Boa Vista, (edição esp. Geografia Agrária), p. 13-32, 2013 b.

FAÇANHA, S. L. O. Aquisições, fusões e alianças estratégicas na configuração da cadeia sucroenergética brasileira. 2012. Tese (Doutorado em Administração) - Faculdade de Economia, Administração e Contabilidade, Universidade de São Paulo, São Paulo, 2012.

FAO FOOD AND AGRICULTURE ORGANIZATION OF THE UNITED NATIONS FAO. Food Outlook: biannual report on global food markets. Rome/ Italy, FAO, 2019.

FURTADO, Celso. Formação Econômica do Brasil. São Paulo, Companhia Editora Nacional, 2005.

FREDERICO, S. Agricultura científica globalizada e fronteira agrícola moderna no Brasil. Revista Confins, Paris, vol. 17, p. 1-17, 2013. 
ARAÚJO, D. F. C.; ARAÚJO SOBRINHO, F. L.

A DINÂMICA DO SETOR SUCROENERGÉTICO NO TRIÂNGULO MINEIRO/ALTO PARANAÍBA

HARVEY, D. (2005). O Neoliberalismo: história e implicações. Trad. Adail Ubirajara Sobral, Maria Stela Gonçalves. 2. ed. São Paulo: Edições Loyola, 2011.

INSTITUTO BRASILEIRO DE GEOGRAFIA E ESTATÍSTICA - IBGE. Divisão

Territorial Brasileira. Rio de Janeiro: IBGE, 2016. Disponível em:

https://www.ibge.gov.br/geociencias/organizacao-do-territorio/estrutura-territorial/23701-

divisao-territorial-brasileira.html?=\&t=o-que-e. Acesso em: 19 jun. 2020.

INSTITUTO BRASILEIRO DE GEOGRAFIA E ESTATÍSTICA - IBGE. Pesquisa

Pecuária Municipal (PPM). Rio de Janeiro: IBGE, 2017. Disponível em:

http://www.sidra.ibge.gov.br. Acesso em: fevereiro/2020.

INSTITUTO BRASILEIRO DE GEOGRAFIA E ESTATÍSTICA - IBGE. Produção Agrícola Municipal (PAM). Rio de Janeiro: IBGE, 2017. Disponível em:

http://www.sidra.ibge.gov.br. Acesso em: fevereiro /2020.

INSTITUTO BRASILEIRO DE GEOGRAFIA E ESTATÍSTICA - IBGE. Produto Interno Bruto Municipal (PIB MUNICIPAL). Rio de Janeiro: IBGE, 2017. Disponível em: <http://www.sidra.ibge.gov.br>. Acesso em: fevereiro/2020.

INSTITUTO BRASILEIRO DE GEOGRAFIA E ESTATÍSTICA - IBGE. Regiões de Influência das cidades 2010. Rio de Janeiro: IBGE, 2010. Disponível em:

<http://www.ibge.gov.br/home/geociencias/geografia>. Acesso em: fevereiro/2020.

INFOCANA. Portal da Infocana. As usinas de Açúcar e Etanol do Brasil 2017. Disponível em:<https://www.infocana.com.br>. Acesso em: fevereiro/2020.

IPCA/IBGE. Índice Nacional de Preços ao Consumidor Amplo. Instituto Brasileiro de Geografia e Estatística (IBGE). Sistema nacional de índices de preços ao consumidor. 2020. Disponível em:

<https://ww2.ibge.gov.br/home/estatistica/indicadores/precos/inpc_ipca/defaultseriesHist .shtm>. Acesso em : 21/02/2020.

MACÊDO, F. S. A reestruturação do setor sucroenergético no Brasil: uma análise do período entre 2005 e 2011. 2011. 71 f. Dissertação (Escola de Economia de São Paulo) FGV, São Paulo, 2011.

MATOS, P. F.; VERISSIMO, T. O. O aumento do arrendamento na Microrregião de Ituiutaba (MG) para produção de cana-de-açúcar. Espaço em Revista, [S.1.], v. 17, p. 18-30, 2015.

MCCORMICK, K. "Communicating bioenergy: a growing challenge”. United States, Biofuels, Bioproducts and Biorefining, 2010.

MINISTÉRIO DO DESENVOLVIMENTO, INDÚSTRIA E COMÉRCIO EXTERIOR MDIC. Estatísticas de Comércio Exterior: Balança Comercial dos Municípios. Disponível em: <https://goo.gl/kdJi7D>. Acesso em: fevereiro /2020. 
ARAÚJO, D. F. C.; ARAÚJO SOBRINHO, F. L.

A DINÂMICA DO SETOR SUCROENERGÉTICO NO TRIÂNGULO MINEIRO/ALTO PARANAÍBA

MESQUITA, F. C. O processo de desconcentração industrial no eixo de desenvolvimento São Paulo-Brasília e a dinâmica do setor de alimentos e bebidas em Uberlândia (MG). 2011. 222f. Dissertação (Mestrado em Geografia). Instituto de Geografia/ÚNICAMP, Campinas, 2011.

MESQUITA, F. C. Evolução da agricultura e transformações da técnica e das relações territoriais no cerrado goiano: a dimensão endógena da expansão da agroindústria canavieira. 2015. 254 f. Tese (Doutorado em Geografia), Instituto de Geografia/ÚNICAMP, Campinas, 2015.

MOREIRA, M. A. Studies on the Rapid Expansion of Sugarcane for Ethanol Production in São Paulo State (Brazil) Using Landsat Data. Remote Sens, [S.1.], v. 2, p. 1057-1076, 2010.

MORAES, M. A. F. D. A desregulamentação do setor sucroalcooleiro do Brasil. Piracicaba, Caminho Editorial, 2000. (Coleção CEPEA).

NEVES, C. C.; HESPANHOL, A. N. A atuação do Estado brasileiro no processo de modernização agrícola e a incorporação do conceito de Microbacias Hidrográficas nas políticas públicas. Caderno Prudentino de Geografia,[S.1.], v. 1, p. 1-16, 2009.

NEVES, M. F. A Dimensão do Setor Sucroenergético: mapeamento e quantificação da safra 2013/14. Ribeirão Preto: Markestrat, 2014. 63 p.

OLIVEIRA, A. U. A mundialização da agricultura brasileira. São Paulo: Iãnde Editorial, 2016.

PEREIRA, M. F. V. Nexos entre campo moderno e economia urbana: situações no Triângulo Mineiro/Alto Paranaíba. In: ANAIS VI SIMPÓSIO INTERNACIONAL DE GEOGRAFIA AGRÁRIA. João Pessoa: UFPB, 2013.

PEREIRA, M. F. V. As 'cidades da cana' no Triângulo Mineiro (Brasil): para uma discussão das implicações territoriais do agronegócio e de seus nexos urbanos. In: ANAIS do $\mathbf{1 5}^{\circ}$

ENCUENTRO DE GEÓGRAFOS DE AMÉRICA LATINA. Anais. La Habana:

Universidad La Habana, 2015.

PEREIRA, M. Os agentes do agronegócio e o uso do território no Triângulo Mineiro/Alto Paranaíba: da moderna agricultura de grãos à expansão recente da cana de açúcar. Revista Do Departamento De Geografia, [S./1.], v. 23, 83-104. 2012.

PEREIRA, M. F. V. A feição regional do circuito espacial produtivo sucroenergético no Triângulo Mineiro e suas implicações territoriais. Campo - Território: Revista de Geografia Agrária, Uberlândia, v. 13, n. 29, p. 162-188, abr., 2018. https://doi.org/10.14393/RCT132907

PESSÔA, V. L. S. Meio técnico-científico-informacional e modernização da agricultura: uma reflexão sobre as transformações no cerrado mineiro. In: MARAFON, G. J.; RUA, J.; RIBEIRO, M. (orgs.) A. Abordagens teórico-metodológicas em geografia agrária. Rio de Janeiro: Ed. UERJ, 2007, p. 255-269. 
ARAÚJO, D. F. C.; ARAÚJO SOBRINHO, F. L.

A DINÂMICA DO SETOR SUCROENERGÉTICO NO TRIÂNGULO MINEIRO/ALTO PARANAÍBA

PITTA, F. T. As transformações na reprodução fictícia do capital na agroindústria canavieira paulista: do Proálcool à crise de 2008. 2016. 420 f. Tese (Doutorado em Geografia), FFLECH/USP, São Paulo, 2016.

PITTA, F. T.; XAVIER, C. V.; NAVARRO, C.; MENDONÇA, M. L. Empresas transnacionais e produção de agrocombustíveis no Brasil. Rede Social de Justiça e Direitos Humanos, Outras Expressões: São Paulo, 2014.

PRADO JUNIOR, C. História Econômica do Brasil. São Paulo: Braziliense, 1963.

RODRIGUES, S; OLIVEIRA, G. Infográfico da Palha a Tomada. 2012. Disponível em: http://edgblogs.s3.amazonaws.com/buzz/files/2012/12/info_258.jpg. Acesso em 14/06/2018.

SAMPAIO, M. A. P. $\mathbf{3 6 0}^{\circ}$ - O périplo do açúcar em direção à Macrorregião Canavieira do Centro-Sul do Brasil. 2015. 826 f. Tese (Doutorado em Geografia), FFLECH/USP, São Paulo, 2015.

SANTOS, H. F. Competitividade regional do setor sucroenergético na mesorregião Triângulo Mineiro/Alto Paranaíba: agricultura científica globalizada e implicações socioambientais no município de Uberaba - MG. 2017. 281f. Dissertação (Mestrado em Geografia), IG/ÚNICAMP, Campinas, 2017.

SANTOS, J. C. Dos canaviais à Etanolatria: o (re) ordenamento territorial do capital e do trabalho no setor sucroalcooleiro da Microrregião Geográfica de Presidente Prudente- SP. 2009. 377 f. Tese (Doutorado em Geografia e Gestão do Território) - Instituto de Geografia, UFU, Uberlândia, 2009.

SANTOS, M. A urbanização brasileira. São Paulo: Hucitec. 1993.

SANTOS, M. A Natureza do Espaço. Técnica e Tempo. Razão e Emoção. São Paulo: Hucitec, 1996.

SANTOS, M. Por uma outra globalização: do pensamento único à consciência universal. 6 ed. Rio de Janeiro: Record, 2000.

SANTOS, M. Técnica, Espaço e Tempo: globalização e meio técnico-científicoinformacional. São Paulo: Hucitec, 1994.

SECRETARIA DE ESTADO DA AGRICULTURA, PECUÁRIA E ABASTECIMENTO DE MINAS GERAIS - SEAPA. Panorama do Comércio Exterior do Agronegócio 2016. Belo Horizonte: SEAPA, 2016. Disponível em:https://goo.g1/5DoHPV. Acesso em: março/2020.

Associação Das Indústrias Sucroenergéticas De Minas Gerais - SIAMIG. Portal da SIAMIG. 2017. Disponível em: <http://www.siamig.com.br〉. Acesso em: fevereiro/2020.

SINDICATO DA INDÚSTRIA DE FABRICAÇÃO DO ÁLCOOL NO ESTADO DE MINAS GERAIS -SIAMIG. Triângulo Mineiro tem prejuízo com usinas de álcool paradas. Disponível em: <http://www.siamig.org.br/>. Acesso em 18/04/2020. 
ARAÚJO, D. F. C.; ARAÚJO SOBRINHO, F. L.

A DINÂMICA DO SETOR SUCROENERGÉTICO NO TRIÂNGULO MINEIRO/ALTO PARANAÍBA

SILVA, W. F.; PEIXINHO, D. M. A expansão do setor sucroenergético em Goiás: a contribuição das políticas públicas. Campo - Território, Uberlândia, v. 07, p. 97-114, 2012.

SZMRECSÁNYI, T.; MOREIRA, E. P. O desenvolvimento da agroindústria canavieira do Brasil desde a Segunda Guerra Mundial. Estudos Avançados, São Paulo, v. 11, n. 5, p. 57 79, 1991.

SZMRECSÁNYI, T. O planejamento da agroindústria canavieira do Brasil: 1930- 1975. São Paulo, Hucitec, 1979.

THOMAZ J. A. O agrohidronegócio no Centro das Disputas Territoriais e de Classe no Brasil do Século XXI. Campo - Território, Uberlândia, v. 5, p. 92-122, 2010.

UNIÃO DA INDÚSTRIA DE CANA-DE-AÇÚCAR - UNICA. Uma análise da concentração na agroindústria canavieira em Minas Gerais. Disponível em: <https://ÚNICA.com.br/>. Acesso em 15 de janeiro de 2020.

VIEIRA, C.A. C. Sentido da colonização e revolução brasileira: crítica de caracterizações do modo de produção colonial. Revista Serviço Social \& Sociedade, São Paulo, Epub, n. 129, p.205-224, ago. 2017.

\section{Autores}

Daniel Féo Castro de Araújo - Possui Graduação em Geografia e Mestrado em Ciências Sociais cursados pela Universidade Federal de Uberlândia (UFU). Atualmente é Doutorando pelo Programa de Pós-Graduação em Geografia da Universidade de Brasília (UnB).

Fernando Luiz Araújo Sobrinho - Possui Graduação em Geografia pela Universidade Federal de Uberlândia (UFU), Mestrado em Arquitetura e Urbanismo pela Universidade de Brasília (UnB) e Doutorado em Geografia pela Universidade Federal de Uberlândia (UFU). Atualmente é Professor do Programa de Pós-Graduação em Geografia, Departamento de Geografia da Universidade de Brasília (UnB).

Artigo recebido em: 20 de maio de 2020.

Artigo aceito em: 25 de junho de 2020.

Artigo publicado em: 26 de junho de 2020. 